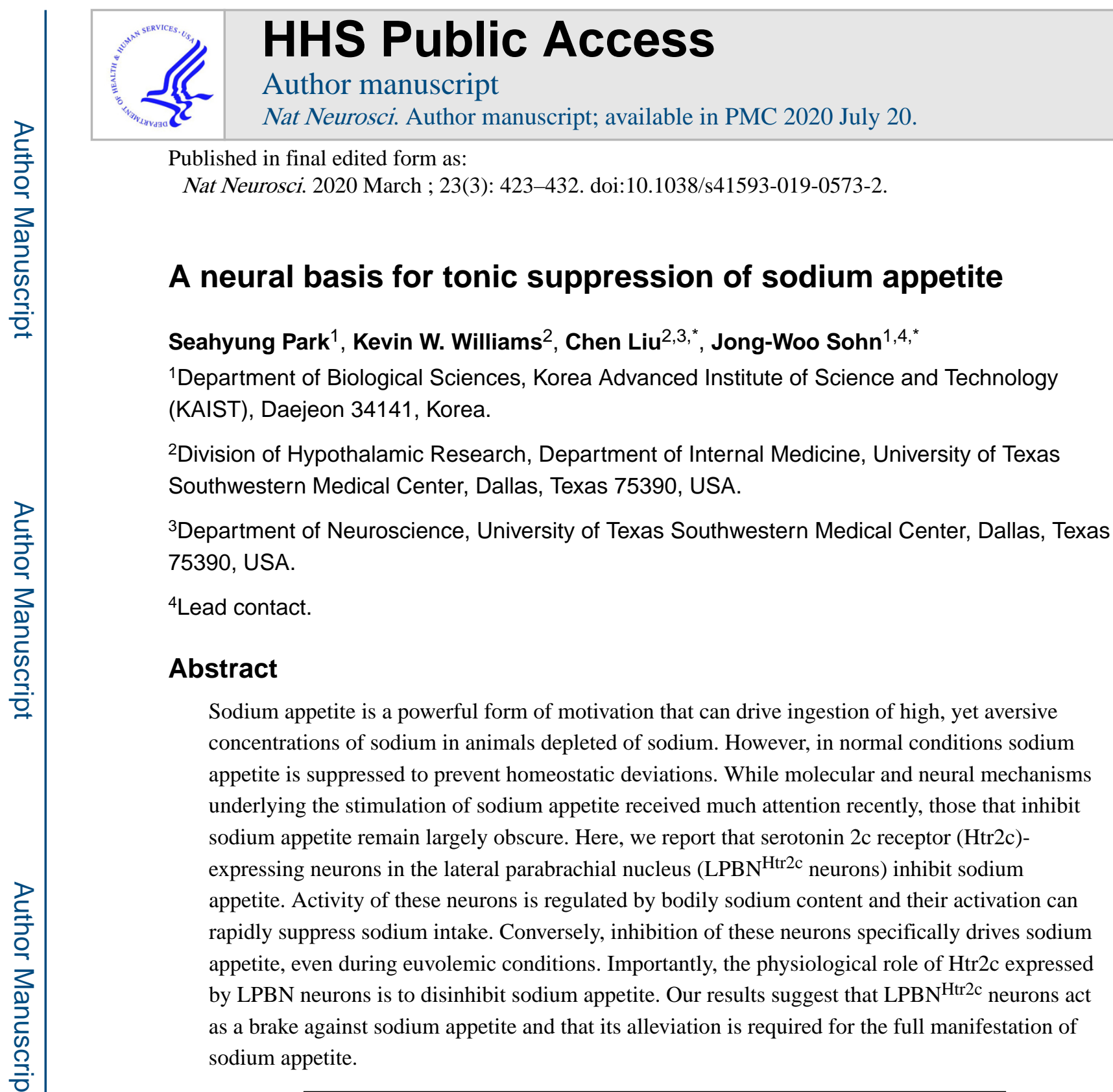

Published in final edited form as:

Nat Neurosci. 2020 March ; 23(3): 423-432. doi:10.1038/s41593-019-0573-2.

\title{
A neural basis for tonic suppression of sodium appetite
}

\author{
Seahyung Park ${ }^{1}$, Kevin W. Williams ${ }^{2}$, Chen Liu $2,3,{ }^{,}$, Jong-Woo Sohn ${ }^{1,4,}$ \\ ${ }^{1}$ Department of Biological Sciences, Korea Advanced Institute of Science and Technology \\ (KAIST), Daejeon 34141, Korea. \\ ${ }^{2}$ Division of Hypothalamic Research, Department of Internal Medicine, University of Texas \\ Southwestern Medical Center, Dallas, Texas 75390, USA \\ ${ }^{3}$ Department of Neuroscience, University of Texas Southwestern Medical Center, Dallas, Texas \\ USA
}

Sodium appetite is a powerful form of motivation that can drive ingestion of high, yet aversive concentrations of sodium in animals depleted of sodium. However, in normal conditions sodium appetite is suppressed to prevent homeostatic deviations. While molecular and neural mechanisms underlying the stimulation of sodium appetite received much attention recently, those that inhibit sodium appetite remain largely obscure. Here, we report that serotonin $2 \mathrm{c}$ receptor (Htr2c)expressing neurons in the lateral parabrachial nucleus (LPBN ${ }^{\mathrm{Htr} 2 \mathrm{c}}$ neurons) inhibit sodium appetite. Activity of these neurons is regulated by bodily sodium content and their activation can rapidly suppress sodium intake. Conversely, inhibition of these neurons specifically drives sodium ppetite, even during euvolemic conditions. Importantly, the physiological role of Htr2c expressed by LPBN neurons is to disinhibit sodium appetite. Our results suggest that $\mathrm{LPBN}^{\mathrm{Htr} 2 \mathrm{c}}$ neurons act sodium appetite.

\footnotetext{
Users may view, print, copy, and download text and data-mine the content in such documents, for the purposes of academic research, subject always to the full Conditions of use:http://www.nature.com/authors/editorial_policies/license.html\#terms

"To whom correspondence should be addressed: Chen Liu, PhD, Departments of Internal Medicine and Neuroscience, The University of Texas Southwestern Medical Center, 5323 Harry Hines Blvd, Dallas, TX75390, USA, Phone: +1-214-648-6442, chen.liu@utsouthwestern.edu, Jong-Woo Sohn MD, PhD, Department of Biological Sciences, Korea Advanced Institute of Science and Technology, 291 Daehak-ro, Yuseong-gu, Daejeon 34141, Republic of Korea, Phone: +82-42-350-2631, jwsohn@kaist.ac.kr. Author contributions

S.P and J.-W.S designed the experiments. S.P conducted experiments and analysed data. C.L and K.W.W provided reagents and expertise. C.L generated and validated Htr2c-2A-iCre mice. S.P and J.-W.S wrote the manuscript. All authors discussed the results and commented on the manuscript.

Data availability

The data that support the findings of this study are available from the corresponding author upon reasonable request.

Competing Financial Interests

The authors declare no competing financial interests.
} 


\section{Introduction}

Sodium ion $\left(\mathrm{Na}^{+}\right)$is an essential mineral to maintain extracellular fluid (ECF)/blood volume. Depletion of sodium leads to an increase in sodium appetite, a strong motivation for animals to consume otherwise aversive concentrations of sodium ${ }^{1}$. Recently, several studies identified neural circuits and molecular mechanisms underlying the promotion of sodium appetite ${ }^{2,3,4}$. However, sodium appetite is not strongly manifested in normal conditions, suggesting that it may be suppressed. Indeed, high concentrations of sodium are typically aversive in the euvolemic state, which is in part mediated by a peripheral mechanism ${ }^{5}$. Yet, a central mechanism underlying suppression of sodium appetite is currently unknown. Previous pharmacological studies suggested that the lateral parabrachial nucleus (LPBN) plays a role in suppressing sodium appetite ${ }^{6,7}$. However, lesions to the LPBN failed to increase sodium appetite ${ }^{8,9}$, which otherwise seems to suggest that the LPBN is not involved in suppressing sodium appetite during euvolemic states. This discrepancy may in part be due to the heterogeneous nature of the LPBN, as this nucleus has been shown to also contain a population of neurons that putatively promote sodium appetite ${ }^{10}$. Thus, the identity of LPBN neuronal subpopulations that suppress sodium appetite remains to be revealed.

Brain serotonin receptors were proposed to control sodium appetite, but the results were not consistent between studies, possibly due to the use of different drugs ${ }^{11,12}$. Likewise, infusions of drugs that affect serotonergic signalling within the LPBN have been shown to have mixed effects on sodium intake ${ }^{13,14}$. These pharmacological studies suggest that serotonergic mechanisms within the LPBN contribute to alter sodium appetite. However, they lack cellular and temporal specificity, which limits the interpretations of these results. Importantly, no information is currently available regarding the physiological role of specific types of serotonin receptors expressed by LPBN neurons in regulating sodium balance.

In order to resolve the issues raised by past studies, we genetically segregated a population of LPBN neurons that express serotonin $2 \mathrm{C}$ receptors (Htr2c) (LPBN ${ }^{\mathrm{Htr} 2 \mathrm{c}}$ neurons), and investigated their potential role and the relevant circuitry in mediating the suppression of sodium appetite. Furthermore, we explored the physiological role of this neuronal population in the control of sodium appetite.

\section{Results}

\section{LPBN $^{\mathrm{Htr2c}}$ neurons are regulated by bodily sodium content}

To examine whether LPBN ${ }^{H t r 2 c}$ neurons respond to high concentrations of sodium, we performed fluorescent in situ hybridisation for Fos. Mice were gastrically loaded via oral gavage with either saline $(154 \mathrm{mM} \mathrm{NaCl})$ or hypertonic saline $(1.5 \mathrm{M} \mathrm{NaCl})$ and then sacrificed 25 minutes later. Consistent with previous reports ${ }^{15,16}$, we saw a robust increase in Fos expression throughout the LPBN (Extended Data Fig. 1). In particular, we found an increase of Fos in Htr2c-expressing neurons (Fig. 1a-c), suggesting that $\mathrm{LPBN}^{\mathrm{Htr} 2 \mathrm{c}}$ neurons are capable of responding to high concentrations of sodium. We also measured Fos within neurons that express serotonin 1B receptor (Htr1b) or forkhead box protein 2 (Foxp2) in the LPBN, which were implicated in the regulation of sodium balance. Htr $1 b$ is another major serotonergic receptor in the LPBN, but we found little difference in Fos expression in Htr1b- 
expressing neurons (Fig. 1c, d). We observed little change in Fos in Foxp2-positive neurons (Fig. 1c, e), consistent with a previous report illustrating that Foxp2 neurons in the LPBN are instead responsive to sodium depletion ${ }^{10}$. We next examined co-localisation between $H t r 2 c$ and other genes that are expressed in the LPBN. We found little co-localisation between $H t r 2 c$ and Htr $1 b(2.1 \pm 0.5 \%)$ (Fig. 1f, g) and a small amount of co-localisation between Htr $2 c$ and Foxp2 (10.7 $\pm 1.9 \%$ ) (Fig. 1f, h). Since oxytocin receptor (Oxtr)expressing LPBN neurons were reported to regulate fluid intake ${ }^{17}$, we measured their colocalisation with $H t r 2 c$ and found that $2.5 \pm 0.3 \%$ of LPBN ${ }^{H t r 2 c}$ neurons co-express Oxtr (Fig. 1f, i). Together, these results suggest that $\mathrm{LPBN}^{\mathrm{Htr} 2 \mathrm{c}}$ neurons are largely distinct from Htr1b neurons, sodium appetite-promoting Foxp2 neurons and fluid intake-regulating Oxtr neurons.

Since hypertonic saline may cause general visceral aversion as well as a sodium-aversive state, thus complicating the interpretation of these results, we next sought to investigate whether LPBN ${ }^{\mathrm{Htr} 2 \mathrm{c}}$ neurons are inhibited during sodium depletion. To target $\mathrm{LPBN}^{\mathrm{Htr} 2 \mathrm{c}}$ neurons, we generated an $\mathrm{Htr} 2 \mathrm{c}-2 \mathrm{~A}-\mathrm{iCre}$ mouse line in which the expression of the codonimproved Cre recombinase (iCre) is under control of the endogenous regulatory sequences of Htr2c gene (Extended Data Fig. 2a). The coding sequences of $\mathrm{Htr} 2 \mathrm{c}$ and $\mathrm{iCre}$ were linked by a viral peptide bridge $2 \mathrm{~A}$ sequence so that the two heterologous genes are initially transcribed from a single open reading frame and later segregated via a ribosomal-skip mechanism ${ }^{18}$. PCR genotyping detected both the targeted Htr2c-2A-iCre and the wild-type $H t r 2 c$ alleles in female heterozygous Htr2c-2A-iCre mice (Extended Data Fig. 2b). Since $H t r 2 c$ is located on the $\mathrm{X}$ chromosome, we observed only one band (targeted) in the male hemizygous Htr2c-2A-iCre mice. Immunohistochemical analysis of Htr2c-2A-iCre activity using a tdTomato reporter revealed the expression of Htr2c in the choroid plexus, a brain region that is known to express high levels of Htr2c (Extended Data Fig. 2c). To then test whether $\mathrm{LPBN}^{\mathrm{Htr} 2 \mathrm{c}}$ neuronal activity is modulated by sodium depletion, we targeted $\mathrm{LPBN}^{\mathrm{Htr} 2 \mathrm{c}}$ neurons using Htr2c-2A-iCre::tdTomato mice. Cell-attached recordings were taken from targeted LPBN ${ }^{\mathrm{Htr} 2 \mathrm{c}}$ neurons from mice maintained 7-8 days either on a control diet $(0.11 \%$ sodium $)$ or a sodium-deficient diet. These diets differed only in sodium content and were otherwise identical in composition. Cells recorded from sodium-depleted mice showed a significant reduction in firing frequency compared to mice that were maintained on a control diet (Fig. 1j, k), suggesting that LPBN ${ }^{\mathrm{Htr} 2 \mathrm{c}}$ neurons are inhibited during sodium depletion. We also recapitulated these results from $\mathrm{Htr} 2 \mathrm{c}-2 \mathrm{~A}-\mathrm{iCre}$ mice injected with AAVDIO-EYFP into the LPBN (Extended Data Fig. 3a-c) to control for any possible transient Cre expression during development. We obtained similar results with $\mathrm{LPBN}^{\mathrm{Htr} 2 \mathrm{c}}$ neurons from mice that were depleted of sodium through subcutaneous injections of furosemide (50 $\mathrm{mg} / \mathrm{kg}$ ) and given access to water and sodium-deficient diet for 1 day (Fig. 11, m). Taken together, these results suggest that $\mathrm{LPBN}^{\mathrm{Htr} 2 \mathrm{c}}$ neurons are responsive to changes in bodily sodium content.

\section{Stimulation of LPBNHtr2c neurons reduces sodium intake}

To test the functional relevance of $\mathrm{LPBN}^{\mathrm{Htr} 2 \mathrm{c}}$ neurons in regulating sodium intake, we established a sodium depletion protocol to promote sodium appetite in mice (Fig. 2a). We unilaterally injected AAV-DIO-hM3Dq-mCherry into the LPBN of Htr2c-2A-iCre mice 
(LPBN ${ }^{\mathrm{Htr2c}-\mathrm{hM} 3 \mathrm{Dq}}$ mice) to specifically activate $\mathrm{LPBN}^{\mathrm{Htr} 2 \mathrm{c}}$ neurons (Fig. 2b). We verified these constructs through current-clamp recordings. Applications of $\mathrm{CNO}(5 \mu \mathrm{M})$ could depolarise membrane potential $(5.2 \pm 1.7 \mathrm{mV}$ in $3 / 3$ cells tested $)$ and induce robust action potentials (Fig. 2c). We tested sodium-depleted $\mathrm{LPBN}^{\mathrm{Htr} 2 \mathrm{c}-\mathrm{hM} 3 \mathrm{Dq}}$ mice in a two-bottle assay, giving them a choice between distilled water and a solution containing $300 \mathrm{mM} \mathrm{NaCl}$. In this condition, we found that $\mathrm{CNO}(1 \mathrm{mg} / \mathrm{kg})$-injected LPBN ${ }^{\mathrm{Htr} 2 \mathrm{c}-\mathrm{hM} 3 \mathrm{Dq}}$ mice showed a decrease in intake of $300 \mathrm{mM} \mathrm{NaCl}$ solution compared to saline-injected controls, while leaving water intake unchanged (Fig. 2d). We confirmed that CNO injections caused no differences in water intake or $300 \mathrm{mM} \mathrm{NaCl}$ intake in AAV-DIO-mCherry-injected Htr2c-2A-iCre mice that were deprived of sodium, validating that $\mathrm{CNO}$ injections alone do not alter sodium intake (Extended Data Fig. 4a, b).

Since chemogenetics offers limited temporal resolution, we tested whether optogenetic activation of $\mathrm{LPBN}^{\mathrm{Htr} 2 \mathrm{c}}$ neurons in a temporally specific manner could recapitulate the chemogenetic results. To this end, we unilaterally injected AAV-DIO-hChR2 (E123T/ T159C)-EYFP (hereafter 'ChETA ${ }_{T C}$-EYFP') into the LPBN of Htr2c-2A-iCre mice that were deprived of sodium (Fig. 2e). Photostimulation of $\mathrm{ChETA}_{\mathrm{TC}}$-EYFP-expressing neurons $(20 \mathrm{~Hz}, 10 \mathrm{~ms}$ pulses, $1 \mathrm{~s}$ duration) generated inward currents in voltage-clamp mode and action potentials in current-clamp mode ( $5 / 5$ cells tested) (Fig. $2 \mathrm{f}$ ). We then designed a closed-loop optogenetic protocol using a lickometer to deliver photostimulation $(10 \mathrm{~Hz}, 10$ ms pulses, $1 \mathrm{~s}$ duration) upon each lick. We tested AAV-DIO-ChETA ${ }_{\mathrm{TC}}$-EYFP-injected mice in a one-bottle assay $(300 \mathrm{mM} \mathrm{NaCl})$ and found that photostimulation locked to each lick could acutely and potently suppress sodium intake whereas photostimulation had no effect in AAV-DIO-EYFP-injected control mice (Fig. 2g, h). Taken together, these results suggest that activation of $\mathrm{LPBN}^{\mathrm{Htr} 2 \mathrm{c}}$ neurons can rapidly suppress sodium intake during sodium depletion.

\section{Inhibition of LPBN ${ }^{\mathrm{Htr2c}}$ neurons promotes sodium intake}

Having shown that activation of $\mathrm{LPBN}^{\mathrm{Htr} 2 \mathrm{c}}$ neurons significantly suppressed sodium intake, we next asked whether inhibiting the activity of these neurons could promote sodium intake. To this end, we injected AAV-DIO-hM4Di-mCherry bilaterally into the LPBN of Htr2c-2AiCre mice (LPBN ${ }^{\mathrm{Htr} 2 \mathrm{c}-\mathrm{hM} 4 \mathrm{Di}}$ mice) (Fig. 3a). We validated this chemogenetic construct in situ through current-clamp recordings. Applications of CNO $(5 \mu \mathrm{M})$ indeed hyperpolarised membrane potential $\left(-5.8 \pm 0.6 \mathrm{mV}\right.$ in $11 / 13$ cells tested) and silenced $\mathrm{LPBN}^{\mathrm{Htr} 2 \mathrm{c}}$ neurons (Fig. 3b). CNO-injected LPBN ${ }^{\mathrm{Htr} 2 \mathrm{c}-\mathrm{hM} 4 \mathrm{Di}}$ mice showed an increase in consumption of 300 $\mathrm{mM} \mathrm{NaCl}$ solution in the two-bottle assay during sodium depletion, while leaving water intake unchanged (Fig. 3c). These data suggest that inhibition of $\mathrm{LPBN}^{\mathrm{Htr} 2 \mathrm{c}}$ neuronal activity can further accentuate sodium intake during sodium depletion.

To test whether inhibition of $\mathrm{LPBN}^{\mathrm{Htr} 2 \mathrm{c}}$ neuronal activity could drive sodium intake in a condition where sodium appetite is not as pronounced, we dehydrated $\mathrm{LPBN}^{\mathrm{Htr} 2 \mathrm{c}-\mathrm{hM} 4 \mathrm{Di}}$ mice (Fig. 3d) before testing them on the two-bottle assay. Again, CNO injections into $\mathrm{LPBN}^{\mathrm{Htr2c}-\mathrm{hM} 4 \mathrm{Di}}$ mice during the dehydrated state increased sodium intake compared to saline-injected controls, whereas water intake did not change (Fig. 3e). Because both sodium depletion and dehydration result in hypovolemia, we tested mice under euvolemic conditions 
to determine whether LPBN ${ }^{\mathrm{Htr} 2 \mathrm{c}}$ neurons are necessary for the suppression of sodium appetite in normal circumstances (Fig. 3f). Interestingly, euvolemic CNO-injected LPBN $^{H t r 2 c-h M 4 D i}$ mice showed increased $300 \mathrm{mM} \mathrm{NaCl}$ intake without changing water intake (Fig. 3g). This increased salt intake was abolished when $300 \mathrm{mM} \mathrm{KCl}$ was used instead of $\mathrm{NaCl}$ (Fig. 3h), but was restored when given $300 \mathrm{mM} \mathrm{NaHCO}$ (Fig. 3i). These results demonstrate the specificity of these behaviours towards sodium. Since sodium intake is typically obtained through feeding instead of ingesting concentrated salt solutions, we tested whether inhibition of LPBN ${ }^{H t r 2 c}$ neuronal activity could also promote intake of food that contains sodium. We tested $\mathrm{LPBN}^{\mathrm{Htr} 2 \mathrm{c}-\mathrm{hM} 4 \mathrm{Di}}$ mice on a fast-refeeding protocol (Fig. $3 \mathrm{j}$ ) using either a control diet or a sodium-deficient diet. CNO-injected LPBN ${ }^{H t r 2 c-h M 4 D i}$ mice showed an increase in food intake compared to saline-injected controls when offered a control diet (Fig. 3k). Remarkably, this apparently orexigenic effect was abolished when $\mathrm{LPBN}^{\mathrm{Htr} 2 \mathrm{c}-\mathrm{hM} 4 \mathrm{Di}}$ mice were instead offered a sodium-deficient diet. These data suggest that the increase in food intake caused by inhibition of LPBN ${ }^{\mathrm{Htr} 2 \mathrm{c}}$ neuronal activity is contingent upon sodium being present in the diet. Finally, we confirmed that CNO injections caused no differences in food intake in AAV-DIO-mCherry-injected control mice on a fast-refeeding paradigm, indicating that $\mathrm{CNO}$ injections alone do not influence the intake of salt-containing food (Extended Data Fig. 4a, c).

\section{Stimulation of LPBN ${ }^{H t r 2 c}$ neurons caused effects unrelated to sodium intake}

While inhibition of LPBN ${ }^{\mathrm{Htr} 2 \mathrm{c}}$ neuronal activity produced effects that were specific to sodium, LPBN ${ }^{\mathrm{Htr} 2 \mathrm{c}-\mathrm{hM} 3 \mathrm{Dq}}$ mice displayed effects that were independent of sodium. CNOinjected LPBN ${ }^{\mathrm{Htr} 2 \mathrm{c}-\mathrm{hM} 3 \mathrm{Dq}}$ mice showed both decreased $300 \mathrm{mM} \mathrm{NaCl}$ intake and water intake during dehydrated conditions, compared to saline-injected controls (Extended Data Fig. 5a, b). These data suggest that while LPBN ${ }^{\mathrm{Htr} 2 \mathrm{c}}$ neurons can decrease sodium intake during dehydration, LPBN ${ }^{H t r 2 c}$ neurons or a subset of them are also capable of reducing water intake under certain circumstances. We also found that activation of LPBN ${ }^{\mathrm{Htr} 2 \mathrm{c}}$ neurons caused sodium-independent decreases in food intake (Extended Data Fig. 5a, c). We speculated that these results may have been mediated by activation of calcitonin gene-related peptide (CGRP) neurons (LPBN ${ }^{\text {CGRP }}$ neurons), which were shown to reduce water intake during dehydration ${ }^{17}$ and to exert anorexigenic effects ${ }^{19}$. Indeed, we found that a subset (34 $\pm 3 \%$ ) of LPBNCGRP neurons overlap with LPBN ${ }^{\mathrm{Htr} 2 \mathrm{c}}$ neurons (Extended Data Fig. 6a, b). However, it is unlikely that LPBNCGRP neurons were responsible for mediating natriorexigenic effects since inhibition of these neurons reduced malaise ${ }^{19,20}$ or increased meal size ${ }^{21}$, which would cause sodium-independent increases in ingestion. Furthermore, activation of LPBNCGRP neurons did not decrease $300 \mathrm{mM} \mathrm{NaCl}$ intake during dehydration ${ }^{17}$. Notably during our optogenetic experiments, we used a photostimulation frequency of $10 \mathrm{~Hz}$ to avoid inducing malaise through LPBNCGRP neurons since they have been shown to induce little malaise at $20 \mathrm{~Hz}^{19}$.

\section{Glutamatergic projections from LPBN ${ }^{\mathrm{Htr} 2 \mathrm{c}}$ neurons to the central amygdala suppress sodium appetite}

To reveal the downstream circuitry of LPBN ${ }^{\mathrm{Htr} 2 \mathrm{c}}$ neurons, we made injections of AAV-DIOEYFP into the LPBN of Htr2c-2A-iCre mice (Fig. 4a and Extended Data Fig. 7a). Among the brain regions that have been implicated in regulating sodium appetite, we found dense 
projections to the bed nucleus of the stria terminalis (BNST), central amygdala (CeA), paraventricular hypothalamus (PVH), parvicellular part of the ventroposterior thalamus (VPPC) and the median preoptic nucleus (MnPO). We also noted projections towards the ventromedial hypothalamus (VMH) and insular cortex (IC), but excluded these areas from further analysis since the VMH has little relevance to sodium appetite and the IC received sparse projections. To identify a candidate site for in vivo terminal photostimulation, we first carried out channelrhodopsin-assisted circuit mapping (CRACM) to identify functional connectivity between $\mathrm{LPBN}^{\mathrm{Htr} 2 \mathrm{c}}$ neurons and downstream regions. We bilaterally injected AAV- DIO-hChR2 (H134R)-mCherry into the LPBN of Htr2c-2A-iCre mice (Fig. 4b and Extended Data Fig. 7b), and then performed whole-cell patch-clamp recordings at target sites to record photo-excitatory postsynaptic currents (pEPSCs) and photo-inhibitory postsynaptic currents (pIPSCs) in voltage-clamp modes at $-60 \mathrm{mV}$ and $-10 \mathrm{mV}$, respectively. We failed to detect either pEPSCs or pIPSCs in the dorsal BNST (dBNST), ventral BNST (vBNST) and PVH (Extended Data Fig 7b). Contrary to this, we detected pEPSCs to the VPPC (1/11 neurons recorded; $9 \%)$, MnPO (1/9 neurons recorded; $11 \%$ ) and CeA (14/25 neurons recorded; 56\%) (Fig. 4b and Extended Data Fig. 7b). We also detected pIPSCs in the CeA (3/24 neurons recorded; 13\%) but speculate that these are not monosynaptic, due to the longer response latencies $(17.7 \pm 0.8 \mathrm{~ms}, \mathrm{n}=3)$. Application of kynurenic acid $(1 \mathrm{mM})$ abolished pEPSCs in the CeA, but upon washout, pEPSCs were recovered (4/4 neurons recorded; 100\%), suggesting that the pEPSCs were glutamatergic (Fig. 4c). Given the abundant connectivity between LPBN ${ }^{\mathrm{Htr} 2 \mathrm{c}}$ neurons and the CeA, we targeted this projection for in vivo stimulation by unilaterally injecting AAV-DIO-hChR2 (H134R)-mCherry into the LPBN of Htr2c-2A-iCre mice and implanting optic fibres ipsilaterally over the CeA (Fig. 4d, e). By using a closed-loop optogenetic to deliver photostimulation $(10 \mathrm{~Hz}, 10 \mathrm{~ms}$ pulses, $1 \mathrm{~s}$ duration) upon each lick, we found that activating the $\mathrm{LPBN}^{\mathrm{Htr} 2 \mathrm{c}} \rightarrow \mathrm{CeA}$ projection was sufficient to suppress sodium appetite in sodium-depleted mice (Fig. 4f, g). Together, these results suggest that $\mathrm{LPBN}^{\mathrm{Htr} 2 \mathrm{c}}$ neurons are able to suppress sodium appetite via glutamatergic projections to the CeA.

\section{Htr2c agonist directly inhibits LPBN ${ }^{H t r 2 c}$ neuronal activity via $K_{\text {ATP }}$ channels}

To investigate the function of Htr2c on LPBN neurons at the electrophysiological level, we made whole-cell patch-clamp recordings from tdTomato-expressing $\mathrm{LPBN}^{\mathrm{Htr} 2 \mathrm{c}}$ neurons. Application of mCPP $(4 \mu \mathrm{M})$, an Htr2c agonist, led to hyperpolarisation in a subset (10/57 cells tested, $17.5 \%$ ) of LPBN ${ }^{\mathrm{Htr} 2 \mathrm{c}}$ neurons (Fig. 5a and Extended Data Fig. 8). This effect was accompanied by a decrease in input resistance with a reversal potential of $-86.9 \pm 4.6$ $\mathrm{mV}(\mathrm{n}=10)$, suggesting the involvement of putative $\mathrm{K}^{+}$conductance (Fig. $\left.5 \mathrm{~b}-\mathrm{d}\right)$. We hypothesised that this increase in $\mathrm{K}^{+}$conductance may have been through ATP-sensitive $\mathrm{K}^{+}$ $\left(\mathrm{K}_{\mathrm{ATP}}\right)$ channels. To test this, we pre-treated neurons with tolbutamide, a $\mathrm{K}_{\mathrm{ATP}}$ channel blocker, before application of $\mathrm{mCPP}$. No hyperpolarisations in response to $\mathrm{mCPP}$ were observed in this condition (Fig. 5e, g) and input resistance was not affected by mCPP (Fig. $5 f, g)$. These data suggest that $\mathrm{K}_{\text {ATP }}$ channels mediate the hyperpolarisation of LPBN neurons upon Htr2c activation. Notably, tolbutamide alone caused a depolarisation of membrane potential $(5.2 \pm 0.9 \mathrm{mV})$ and an increase of input resistance in the majority of cells tested ( $\mathrm{n}=13 / 20)$ (Fig. 5e-g), suggesting that $\mathrm{K}_{\text {ATP }}$ channels may contribute to the resting membrane potential of $\mathrm{LPBN}^{\mathrm{Htr} 2 \mathrm{c}}$ neurons. Since mCPP may also have affinity for 
Htr1b, we pre-treated slices with SB216641 (200 nM), an Htr1b antagonist. The effects of $\mathrm{mCPP}$ persisted in this condition, suggesting that the hyperpolarisation is independent of Htr 1b (Extended Data Fig. 9a, b). Pre-treatment of slices with synaptic blockers $(0.5 \mu \mathrm{M}$ TTX, $1 \mathrm{mM}$ kynurenic acid, $50 \mu \mathrm{M}$ picrotoxin) also did not change the effects of mCPP, suggesting that these effects were postsynaptic (Extended Data Fig. 9c, d). A previous report suggested that a subset of neurons within the PVH projecting to the LPBN is calorically responsive ${ }^{22}$. Thus, we tested whether a similar phenomenon could be observed in $\mathrm{LPBN}^{\mathrm{Htr} 2 \mathrm{c}}$ neurons. However, fasting mice for 18 hours did not change the amplitude or proportion of responses to mCPP. These data suggest that LPBN Htr2c responses are not influenced by changes in caloric state (Extended Data Fig. 9e-g).

\section{Deletion of Htr2c in LPBN reduces sodium intake during hypovolemia}

To test the physiological role of Htr2c in the LPBN in regulating sodium intake, we generated LPBN-specific KO mice by injecting AAV-CMV-Cre-GFP directly into the LPBN of Htr2 $\mathrm{c}^{\text {flox/Y }}$ mice (LPBN ${ }^{\mathrm{Htr} 2 \mathrm{cKO}}$ mice) (Fig. 6a). We confirmed successful deletion of $H$ tr $2 c$ in the LPBN through fluorescent in situ hybridisation (Fig. 6b, c). Subjecting LPBN $^{\mathrm{Htr} 2 \mathrm{cKO}}$ mice to two-bottle choice experiments revealed that AAV-CMV-Cre-GFPinjected mice had decreased intake of $300 \mathrm{mM} \mathrm{NaCl}$ solution in both the sodium-depleted state and the dehydrated state compared to AAV-CMV-GFP-injected controls (Fig. 6d, e). However, food intake was unaltered in $\mathrm{LPBN}^{\mathrm{Htr} 2 \mathrm{cKO}}$ mice regardless of the diet used (Fig. 6f). Taken together, these results suggest that Htr2c can inhibit LPBN neurons and thus act to disinhibit sodium intake, but plays no physiological role in regulating caloric appetite.

We speculated that the discrepancy between results obtained from $\mathrm{LPBN}^{\mathrm{Htr} 2 \mathrm{cKO}}$ mice and direct activation of LPBN ${ }^{\mathrm{Ht} 2 \mathrm{c}}$ neurons was presumably due to the degree of activation that occurs on these neurons. Removal of Htr2c would only be expected to have noticeable effects in conditions where serotonin is present, whereas the effects of chemogenetic modulation are not contingent upon this. Thus, serotonin release onto these neurons presumably occurs during conditions of hypovolemia (i.e. by sodium depletion or dehydration) but not during fasting, which may account for the lack of effect on food intake in $\mathrm{LPBN}^{\mathrm{Htr} 2 \mathrm{cKO}}$ mice, in spite of the presence of sodium in the diet. We tested this hypothesis by comparing the intake of water and $300 \mathrm{mM} \mathrm{NaCl}$ solution in euvolemic mice. In this state, we observed no difference in these measures between $\mathrm{LPBN}^{\mathrm{Ht} 2 \mathrm{cKO}}$ mice and control mice (Fig. $6 \mathrm{~g}$ ), suggesting that the effects of $\mathrm{Htr} 2 \mathrm{c}$ deletion in the LPBN are dependent on the hypovolemic state.

Finally, to identify sources of serotonin onto LPBN ${ }^{\mathrm{Htr} 2 \mathrm{c}}$ neurons, we injected wild-type mice with retrobeads (Extended Data Fig. 10a) and then counterstained upstream-labelled sites for serotonin (5-HT). Interestingly, we found co-localisation of 5-HT and retrobead-labelled cells in the dorsal raphe nucleus (DR) and the median raphe nucleus (MnR) (Extended Data Fig. 10b), suggesting that these raphe nuclei may be capable of modulating the LPBN neurons through serotoninergic projections. 


\section{Discussion}

Maintenance of sodium content and body fluid volume is essential for survival and growth.

Depletion of sodium is sensed through hypovolemia, which results in both increased retention of sodium and increased ingestion of sodium, the latter being manifested as sodium appetite. However, previous studies have consistently seen a delay between the onset of hypovolemia and sodium appetite, leading to formulation of the "disinhibition hypothesis" 23 which proposed the relief of sodium appetite from inhibitory mechanisms. Although past studies have shown inhibitory influences over sodium appetite, whether removal of any of those influences can drive increased sodium appetite during euvolemic conditions has remained contentious. Here, we describe a subpopulation of neurons in the LPBN that suppresses sodium appetite. Animals tend to avoid ingesting high concentrations of sodium under normal circumstances and our results suggest that $\mathrm{LPBN}^{\mathrm{Htr} 2 \mathrm{c}}$ neurons may be a central substrate that facilitates this suppression of sodium appetite. Furthermore, we show that inhibition of these neurons is indeed able to drive sodium appetite, independently of thirst, even during euvolemic conditions. Our results were not restricted to sodium solutions, but also extended to sodium-containing foods, suggesting that certain aspects of appetite regulation by the LPBN may be coupled to osmoregulation. This finding was somewhat surprising since LPBN lesion studies showed either no increase ${ }^{8}$ or reduced sodium appetite $^{9}$, which further highlights the heterogeneity of the LPBN neurons and the need for genetic segregation of its subpopulations.

Recent studies provided evidence that synergy between aldosterone and angiotensin II signalling underlie the promotion of sodium appetite ${ }^{4}$. Our results suggest that disinhibition of sodium appetite from the influence of the $\mathrm{LPBN}^{\mathrm{Htr} 2 \mathrm{c}}$ neurons may also play an important complementary role. We note that synergy and disinhibition are not mutually exclusive mechanisms since the activity of $\mathrm{LPBN}^{\mathrm{Htr} 2 \mathrm{c}}$ neurons might also be modulated by aldosterone and angiotensin II signalling. Indeed, aldosterone-sensitive $11 \beta$-hydroxysteroid dehydrogenase type 2 (HSD2) neurons within the NTS (NTS ${ }^{\mathrm{HSD} 2}$ neurons), which are considered to be the neural substrate for aldosterone signalling, have been shown to project to the $\mathrm{LPBN}^{3,4}$. However, we find it unlikely that these neurons mediate their effects by directly terminating on $\mathrm{LPBN}^{\mathrm{Htr} 2 \mathrm{c}}$ neurons, since $\mathrm{NTS}^{\mathrm{HSD} 2}$ neurons have been shown to be Phox 2b-positive neurons ${ }^{24}$, which are selectively glutamatergic ${ }^{25}$. $\mathrm{NTS}^{\mathrm{HSD} 2}$ neurons project instead to Foxp2 neurons within the LPBN (LPBN ${ }^{\text {Foxp2 }}$ neurons), putatively sodium appetite-promoting neurons ${ }^{3,4}$, which we have found not to overlap significantly with $\mathrm{LPBN}^{\mathrm{Htr} 2 \mathrm{c}}$ neurons in the central LPBN. The presence of both sodium appetite promoting and suppressing neurons in the LPBN is of interest, raising the possibility that these subpopulations may even interact with each other.

We found that $\mathrm{LPBN}^{\mathrm{Htr} 2 \mathrm{c}}$ neurons were responsive to bodily sodium content; responding to high concentrations of gastrically-loaded sodium and scaling down their activity during sodium depletion. While it is likely that $\mathrm{LPBN}^{\mathrm{Htr} 2 \mathrm{c}}$ neurons receive baroreceptive information via the nucleus tractus solitarius (NTS) ${ }^{8}$, it is well known that PBN neurons, particularly those in the waist region, are responsive to tastants ${ }^{26,27}$. Previous studies regarding the detection of salt tastants have shown that the detection of aversive concentrations of salt occur in an amiloride-insensitive, non-sodium specific manner ${ }^{28}$. This 
raises the possibility that $\mathrm{LPBN}^{\mathrm{Htr} 2 \mathrm{c}}$ neurons mediate aversion towards high concentrations of salt in general. However, we find this to be unlikely as we found that chemogenetic inhibition of $\mathrm{LPBN}^{\mathrm{Htr} 2 \mathrm{c}}$ neurons selectively increased intake of sodium salts, but not potassium salts. Our results suggest that animals are able to translate decreased activity of $\mathrm{LPBN}^{\mathrm{Htr} 2 \mathrm{c}}$ neurons into a sodium-specific behaviour, as opposed to a generalised intake of all salts. Nevertheless, the nature of the information conveyed by LPBN ${ }^{\mathrm{Htr} 2 \mathrm{c}}$ neurons appears to be sufficient to regulate sodium intake on a rapid timescale during sodium depletion, as seen in our optogenetic experiments.

Our experiments showed that these rapid effects appear to be mediated by projections to the $\mathrm{CeA}$, which has been anatomically implicated in regulating sodium appetite ${ }^{29,30}$. We also found that $\mathrm{LPBN}^{\mathrm{Htr} 2 \mathrm{c}}$ neurons project to the vBNST, which has been shown to be a functionally relevant target of the angiotensin II receptor 1a (AT1a)-expressing neurons within the subfornical organ (SFO) $\left(\mathrm{SFO}^{\mathrm{AT} 1 \mathrm{a}}\right.$ neurons) ${ }^{2}$ and $\mathrm{NTS}^{\mathrm{HSD} 2}$ neurons ${ }^{4}$, which both promote sodium appetite. Although this raised the attractive possibility that $\mathrm{LPBN}^{\mathrm{Htr} 2 \mathrm{c}}$ neurons may reduce sodium appetite by sending inhibitory projections to vBNST neurons innervated by SFO ${ }^{\mathrm{AT} 1 \mathrm{a}}$ and $\mathrm{NTS}^{\mathrm{HSD} 2}$ neurons, we failed to detect pIPSCs from $\mathrm{LPBN}^{\mathrm{Htr} 2 \mathrm{c}}$ neurons to vBNST neurons. In addition, the absence of pEPSCs from $\mathrm{LPBN}^{\mathrm{Htr} 2 \mathrm{c}}$ neurons to vBNST neurons likely ruled out the possibility that $\mathrm{LPBN}^{\mathrm{Htr} 2 \mathrm{c}}$ neurons inhibit vBNST neurons via excitation of interneurons. While we cannot rule out the possibility that $\mathrm{LPBN}^{\mathrm{Htr} 2 \mathrm{c}}$ neurons may be able to influence the vBNST on a slower time scale via neuromodulators, this would not account for the rapid effects observed from our closed-loop optogenetic stimulation of LPBN ${ }^{\mathrm{Htr} 2 \mathrm{c}}$ neurons. Nevertheless, given the dense GABAergic projections between the CeA and $\mathrm{vBNST}^{31,32}$, the signals from the SFO ${ }^{\mathrm{AT} 1 \mathrm{a}}$ and NTS ${ }^{\mathrm{HSD} 2}$ neurons possibly act antagonistically to those from $\mathrm{LPBN}^{\mathrm{Htr} 2 \mathrm{c}}$ neurons, at the downstream level between the CeA and vBNST. Identifying whether the $\mathrm{SFO}^{\mathrm{AT} 1 \mathrm{a}} \rightarrow \mathrm{vBNST}$ or $\mathrm{NTS}^{\mathrm{HSD} 2} \rightarrow$ vBNST projections are able to promote sodium intake in spite of $\mathrm{LPBN}^{\mathrm{Htr} 2 \mathrm{c}}$ neuronal activation will also be informative regarding the hierarchy and interplay between these sodium appetite-regulating populations. Finally we noted a strong projection to the dBNST, which was recently implicated in conveying chemosensory signals related to sodium $^{33}$. However, we failed to detect any functional connectivity between dBNST and LPBN $^{\mathrm{Htr} 2 \mathrm{c}}$ neurons through CRACM.

Involvement of serotonin in regulating sodium appetite through actions at the LPBN has been known through previous studies ${ }^{13,14}$. However, the exact electrophysiological manifestations and physiological relevance of these effects were not explored. We found that activation of $\mathrm{Htr} 2 \mathrm{c}$ causes inhibition of LPBN ${ }^{\mathrm{Htr} 2 \mathrm{c}}$ neurons, suggesting that serotonergic signalling within LPBN may serve to inhibit $\mathrm{LPBN}^{\mathrm{Htr} 2 \mathrm{c}}$ neurons in a certain context. Because Htr2c is considered an excitatory receptor, which is linked to Gq proteins, this result was somewhat surprising. However, previous reports suggest that $\mathrm{Htr} 2 \mathrm{c}$ is able to engage both $\mathrm{Gi}$ and $\mathrm{Gq}$ related responses, as measured by decreases in cAMP production and chloride currents, which were abolished by pertussis toxin (PTX) and anti-Go nucleotides, respectively ${ }^{34,35}$. Furthermore, Gi signalling has been linked to activation of $\mathrm{K}_{\mathrm{ATP}}$ channels in cardiac myocytes ${ }^{36}$. 
The decrease in sodium appetite during hypovolemia, by conditionally knocking out $\mathrm{Htr} 2 \mathrm{c}$ from the LPBN ( $\mathrm{LPBN}^{\mathrm{Htr} 2 \mathrm{cKO}}$ mice), suggests that ECF volume may regulate serotonergic signalling in the LPBN, which in turn controls sodium intake by modulation of LPBN ${ }^{\mathrm{Htr} 2 \mathrm{c}}$ neuronal activity. We found serotonergic projections to LPBN from the DR and MnR, consistent with other reports ${ }^{37,38}$. The MnR is of particular interest since electrical stimulation of $\mathrm{MnR}$ has been shown to increase blood pressure, which was attenuated in the presence of an inhibitor of tryptophan hydroxylase ${ }^{39}$. On the other hand, electrical stimulation of the DR was shown to bidirectionally modulate blood pressure in a serotoninindependent manner. Thus serotonergic cells in the MnR may possibly engage neural circuitry to defend against hypovolemia; an appropriate behavioural output being increased sodium intake. In this model, serotonin release from the MnR onto the LPBN signals hypovolemia, which would act to disinhibit sodium appetite by acting on LPBN ${ }^{\mathrm{Htr} 2 \mathrm{c}}$ neurons. Detailed understanding of how blood pressure as well as bodily sodium content regulate serotonergic signalling and $\mathrm{LPBN}^{\mathrm{Ht} 2 \mathrm{c}}$ neuronal activity may be key in the development of novel anti-hypertensive agents via suppression of sodium appetite.

\section{Online Methods}

\section{Animals}

Htr2c-2A-iCre mice were generated by conventional gene targeting in C57BL/6 embryonic stem cells. All resulting chimeras displaying germline transmission were bred to mice of C57BL/6 background. The F1 pups from male chimeras were screened for those carrying the $\mathrm{Htr} 2 \mathrm{c}^{i C r e}$ allele using PCR genotyping with the following primers CL-9631: 5'TTTGTGGGAAGGCCTGTAAC-3'; CL-10057: 5'-GGAGTGGGGGACTT TCCTAC-3'; CL-R309: 5' - TCCCTCACATCCTCAGGTTC-3'. Htr2 $c^{\text {flox } / Y}$ mice have been described previously ${ }^{40}$. Htr2c-2A-iCre mice were crossed with tdTomato (Ai14) reporter mice, Gt(ROSA)26Sortm14(CAG-tdTomato)Hze/J, for patch-clamp recordings. Mice were housed at $22-24{ }^{\circ} \mathrm{C}$ with a $12 \mathrm{~h}$ light:12 h dark cycle on normal chow (Teklad, 2018S). Sodium deficient diet (Research Diets, D08070603) and control diet (Teklad, TD94045) were only given during experimental procedures. Food and water was provided ad libitum when experiments were not being conducted. 6- to 8-week-old male mice were used for surgery. Allocation of animals to control or experimental groups were randomised and counter balanced. The investigator was not blinded to group allocation. The investigator was not blinded to experimental or control groups during behavioural experiments. However, all behavioural experiments involved stereotaxic injections thus blinding the investigator to whether the mice passed or failed viral expression exclusion criteria. All procedures were conducted according to the Korean Advanced Institute of Science and Technology (KAIST) Guidelines for the Care and Use of Laboratory Animals and were approved by the Institutional Animal Care and Use Committee (Protocol No. KA2018-80).

\section{Stereotaxic injections}

Mice were anaesthetised under isoflurane and had their heads fixed in a stereotaxic frame. Lidocaine ( $2 \% \mathrm{wt} / \mathrm{vol})$ was applied topically for pre-emptive analgesia. The skull was drilled and a $33 \mathrm{~g}$ blunt NanoFil needle (World Precision Instruments, NF33BL-2) was lowered to the target region (LPBN: A-P $5.22 \mathrm{~mm}$, M-L $1.3 \mathrm{~mm}$, D-V $3.5 \mathrm{~mm}$ ) towards the 
target nucleus. For chemogenetic experiments, $0.08-0.15 \mu \mathrm{l}$ of either AAV5-hSyn-DIOhM3q-mCherry virus (University of North Carolina Vector Core; $3.8 \times 10^{12}$ molecules/ $\mu \mathrm{l}$ ), AAV2-hSyn-DIO-hM4Di-mCherry (University of North Carolina Vector Core; $3.7 \times 10^{12}$ molecules/ $\mu$ l) or AAV2-hSyn-DIO-mCherry (University of North Carolina Vector Core; $5.6 \times 10^{12}$ molecules/ $\mu \mathrm{l}$ ) was injected into the LPBN of Htr2c-2A-iCre mice using a Hamilton syringe at a rate of $0.2 \mu \mathrm{l} / \mathrm{min} .7-10$ minutes after injection of the virus, the needle was then removed slowly. For optogenetic experiments, $0.12-0.14 \mu \mathrm{l}$ of AAV5-EF1a-DIO-hChR2 (E123T/T159C)-p2A-EYFP (University of North Carolina Vector Core; $5.1 \times 10^{12}$ molecules/ $\mu$ l), AAV5-EF1a-DIO-EYFP (University of North Carolina Vector Core; $6.5 \times 10^{12}$ molecules/ $\mu$ l), AAV2-EF1a-DIO-hChR2 (H134R)-p2A-mCherry virus (University of North Carolina Vector Core; $5.1 \times 10^{12}$ molecules/ $\mu$ l) or AAV2-EF1a-DIO-mCherry virus (University of North Carolina Vector Core; $3.2 \times 10^{12}$ molecules/ $\mu$ ), was injected unilaterally. Monofibre optic cannulas ( $200 \mu \mathrm{m}$ diameter core; $\mathrm{NA}=0.37$;) were implanted at A-P $5.22 \mathrm{~mm}$, M-L $1.3 \mathrm{~mm}$, D-V $3.2 \mathrm{~mm}$ for LPBN soma photostimulation and A-P 1.22, M-L 2.5, D-V 4.1mm for CeA terminal photostimulation, with Super-Bond C\&B (Sun Medical). For conditional Htr2c deletion experiments, AAV5-CMV-GFP (University of North Carolina Vector Core; $4.7 \times 10^{12}$ molecules/ $\mu$ l) or AAV5-CMV-Cre-GFP (University of North Carolina Vector Core; $4.5 \times 10^{12}$ molecules/ $\mu$ l) were injected into the LPBN of $\mathrm{Htr} 2 \mathrm{c}^{\mathrm{flox} / \mathrm{Y}}$ mice. Mice were kept on a heating pad and watched closely until regaining movement. Mice were handled for 1 week before starting behavioural experiments. At least 3 weeks of recovery was given before starting behavioural experiments. For anterograde tracing experiments, $0.1-0.16 \mu \mathrm{l}$ of AAV5-EF1a-DIO-EYFP (University of North Carolina Vector Core; $6.5 \times 10^{12}$ molecules/ $\mu$ l) were injected into the LPBN of Htr2c-2A-iCre mice. Mice were sacrificed 3 weeks later. For retrograde tracing, 0.12-0.17 $\mu \mathrm{l}$ of red retrobeads (Lumafluor) were injected into the LPBN of Htr2c-2A-iCre mice. Mice were sacrificed 5 days later.

\section{Immunohistochemistry}

Mice were anaesthetised with isoflurane and transcardially perfused with saline, followed by $4 \%$ paraformaldehyde (PFA) and had their brains extracted. Brains were fixed overnight in PFA at $4{ }^{\circ} \mathrm{C}$. After fixation, brains cryo-protected in a $30 \%$ sucrose solution at $4{ }^{\circ} \mathrm{C}$ for $1-2$ days. Brains were then frozen in FSC Clear (Leica) and sliced using a cryotome (Leica, CM1850) at $30 \mu \mathrm{m}$ thickness. Slices were incubated in a blocking solution (2\% goat serum, $0.3 \%$ Triton-X, in 0.1 M PBS) for 1 hour at room temperature on a shaking plate. Slices were then incubated in primary antibodies, 1:1,000 rabbit anti-CGRP (Bachem, T4032) or 1:1,000 rabbit anti-serotonin (Immunostar, 20080) solution for 17 hours at $4{ }^{\circ} \mathrm{C}$. Slices were then washed for 10 minutes, three times in PBS. Slices were then incubated in a secondary antibody solution for 1 hour. Secondary antibody, Goat anti-rabbit 647 (Molecular Probes, A21245) was used at 1:200 dilution. Slices were then washed for 10 minutes, three times in PBS. DAPI was added $(1: 10,000)$ during the second PBS washing. Slices were then mounted on a microscope glass and mounted with DAKO mounting media. $Z$ stack images were acquired with a confocal microscope (Zeiss, LSM780) and maximum intensity Z projected through ImageJ (NIH) software. 


\section{Fluorescent in situ hybridisation}

Mice were anaesthetised with isoflurane and transcardially perfused with DEPC-PBS, followed by $4 \%$ paraformaldehyde (PFA) and had their brains extracted. Brains were fixed overnight in PFA at $4{ }^{\circ} \mathrm{C}$. After fixation, brains were cryo-protected in a $30 \%$ sucrose solution at $4{ }^{\circ} \mathrm{C}$ for $1-2$ days. Brains were then frozen in O.C.T compound (Tissue-Tek, 4583 ) and sliced using a cryotome (Leica, CM1850) at $14 \mu \mathrm{m}$ thickness at the KAIST Biocore center. Slices were stored in a cryoprotectant solution $(500 \mathrm{ml} 0.1 \mathrm{M}$ phosphate buffer (pH 7.2), $300 \mathrm{ml}$ ethylene glycol, $300 \mathrm{~g}$ sucrose, remaining volume filled with DW to a total of $1 \mathrm{~L}$ ) at $-20^{\circ} \mathrm{C}$ until further processing. mRNA signals were hybridized using RNAscope, according to the manufacturer's instructions. Protease treatment was done for 15 minutes at $40{ }^{\circ} \mathrm{C}$ using the HybEZ Hybridization System. Mm-Htr1b (Ref 315861), Mm-Foxp2 (Ref 428791), Mm-Oxtr (Ref 412171), Mm-Fos-C2 (Ref 316921-C2) and Mm-Htr2c-C3 (Ref 401001-C3) were used to detect Htr1b, Foxp2, Oxtr, Fos and Htr2c mRNA respectively. For Fos experiments, wild-type mice were acclimatised to oral-gavages by intragastrically loading them with saline for 1 week $(10 \mu \mathrm{l} / \mathrm{g})$. On the day of the assay, normal saline (154 $\mathrm{mM} \mathrm{NaCl})$ or hypertonic $(1.5 \mathrm{M} \mathrm{NaCl})$ were gastrically loaded into animals at $10 \mu \mathrm{l} / \mathrm{g}$. Animals were sacrificed 25 minutes later. For conditional knockout experiments, EGFP-C1 (Ref 400281) and a custom made Mm-Htr2c-01-C3 probe (Ref 503281) that recognizes base pairs 724-1241 of NM_008312.4 were used to visualise GFP and Htr2c mRNA respectively. $\mathrm{Z}$ stack images were acquired with a confocal microscope (Zeiss, LSM780) and maximum intensity $\mathrm{Z}$ projected through ImageJ (NIH) software.

\section{Behavioural experiments}

For fast-refeeding experiments, mice were housed in single cages for at least 1 week before conducting assays. The day before the assay, mice body weights were measured, food was cleared and bedding was replaced. Stock CNO was dissolved in DPBS at $8.75 \mathrm{mM}$. Stock $\mathrm{CNO}$ was diluted in sterile saline and administered intraperitoneally at $1 \mathrm{mg} / \mathrm{kg}$, whereas DPBS was administered by diluting in sterile saline at a ratio consistent with CNO injections. In the text, saline injections refer to DPBS diluted in sterile saline. Injections were given 18 hours after fasting, at 10:00 on the day of the assay. Food was then reintroduced (either normal chow, sodium deficient diet or control diet) and then food intake and body weight were measured at 1,2, and 4 hours after i.p. injections.

For two-bottle assays, mice were housed in single cages equipped with 2 volumetric drinking tubes (MedAssociates), containing either distilled water or $300 \mathrm{mM} \mathrm{NaCl}$ for at least 1 week before conducting assays. For sodium depletion, furosemide was administered subcutaneously at $50 \mathrm{mg} / \mathrm{kg}$ at 19:30 on the day before the assay. After furosemide injections, chow diet was replaced with a sodium deficient diet (Research Diets, D08070603), bedding was replaced and $300 \mathrm{mM} \mathrm{NaCl}$ bottles were removed. At 18:45 on the day of the assay, mice were injected with either saline or CNO in a counter balanced randomized manner. Water and sodium deficient diet was then removed. Assays began at 19:30, upon the re-introduction of distilled water and $300 \mathrm{mM} \mathrm{NaCl}$ solutions.

For one-bottle assays, mice were acclimated to lickometer-installed cage before testing. Mice were trained to use the lickometer-connected sipper bottle by depriving them of water 
and introducing them into the lickometer-installed cage the next day. Training was considered successful when mice made at least 100 licks within 30 minutes. On the day before testing, sodium depletion was carried out using the same sodium depletion protocol for two bottle assays. On the day of testing, mice were first habituated in the testing cage for 15 minutes without food, water or $300 \mathrm{mM} \mathrm{NaCl}$. A bottle containing $300 \mathrm{mM} \mathrm{NaCl}$ was then introduced and the number of licks were measured for 20 minutes. Both no photostimulation and photostimulation conditions were conducted at the same time of day for each mouse. All one-bottle assays were conducted during the dark-cycle.

For dehydration, both distilled water and $300 \mathrm{mM} \mathrm{NaCl}$ bottles were removed at 23:30 on the day before the assay. At 18:45 on the day of the assay, mice were injected with either saline or CNO in a counter balanced randomized manner. Normal chow was removed and bedding was replaced. Assays began at 19:30, upon the re-introduction of distilled water and $300 \mathrm{mM} \mathrm{NaCl}$ solutions.

For euvolemic experiments, distilled water, $300 \mathrm{mM}$ salt solution and normal chow were available ad libitum until saline/CNO injections, at 18:45 on the day of the assay. Distilled water, $300 \mathrm{mM}$ salt solution and normal chow were then removed and the bedding was replaced. Assays began at 19:30, upon the re-introduction of distilled water and $300 \mathrm{mM}$ salt solutions. All chemogenetic experiments were done as paired comparisons, assays being repeated at least 4 days later, with the treatments switched (i.e. saline to $\mathrm{CNO}$ or $\mathrm{CNO}$ to saline). Flox experiments were conducted using littermates. The investigator was not blinded to experimental or control groups.

\section{Photostimulation protocol}

Patch cords (1 m long, $200 \mathrm{~mm}$ core diameter; Doric Lenses) were connected from a rotary joint (Doric Lenses) to monofibre optic cannulae through zirconia sleeves (Doric Lenses). A custom-made lickometer (Arduino) was used to detect licks and drive photostimulation upon each lick $(10 \mathrm{~Hz}, 10 \mathrm{~ms}$ pulse width, $1 \mathrm{~s}$ duration). Blue light was generated from a laser (473 nm; Laserglow) at an intensity of $8.2-11.3 \mathrm{~mW}$ as measured at the tip of the optic cannula. We estimated the light power at the LPBN to be around $9.2-12.67 \mathrm{~mW} / \mathrm{mm}^{2}$ and at the CeA to be $14.4-21 \mathrm{~mW} / \mathrm{mm}^{2}$ as calculated by an online light transmission calculator (http://web.stanford.edu/group/dlab/cgi-bin/graph/chart.php).

\section{Histology}

After the completion of behavioural experiments, mice were perfused with saline and $4 \%$ PFA. Brains were extracted and post-fixed for 24 hours at $4{ }^{\circ} \mathrm{C}$ in $4 \%$ PFA. $50 \mu \mathrm{m}$ sections were then made on a vibratome (Leica VT1200S) and mounted with Vectashield mounting medium with DAPI, Hard Set (Vector, H-1500). Mice were excluded from analysis if vector expression was absent, incomplete or outside the area of interest. For optogenetic experiments, optic fibre tip locations were also validated and excluded when off target.

\section{Electrophysiology}

Whole-cell patch-clamp recordings from Htr2c neurons were made from the LPBN of 3-6 week old male and female mice. Mice were anaesthetized with isoflurane and transcardially 
perfused with a cutting solution $\left(220 \mathrm{mM}\right.$ sucrose, $26 \mathrm{mM} \mathrm{NaHCO}_{3}, 2.5 \mathrm{mM} \mathrm{KCl}, 1 \mathrm{mM}$ $\mathrm{NaH}_{2} \mathrm{PO}_{4}, 5 \mathrm{mM} \mathrm{MgCl}_{2}, 1 \mathrm{mM} \mathrm{CaCl}_{2}, 10 \mathrm{mM}$ glucose, $\mathrm{pH}$ 7.3-7.35). The mice were then decapitated, and the entire brain was removed and immediately submerged in ice cold, carbogen-saturated cutting solution. $300 \mu \mathrm{m}$ coronal sections were cut from the LPBN with a Leica VT1200S Vibratome and then incubated in oxygenated storage solution $(123 \mathrm{mM}$ $\mathrm{NaCl}, 26 \mathrm{mM}, \mathrm{NaHCO}_{3}, 2.8 \mathrm{mM} \mathrm{KCl}, 1.25 \mathrm{mM} \mathrm{NaH}_{2} \mathrm{PO}_{4}, 1.2 \mathrm{mM}, \mathrm{MgSO}_{4}, 2.5 \mathrm{mM}$ $\mathrm{CaCl}_{2}, 10 \mathrm{mM}$ glucose $\mathrm{pH} 7.3-7.35$ ) at $34{ }^{\circ} \mathrm{C}$ for at least 1 hour before recording. Slices were transferred to the recording chamber and allowed to equilibrate for 10 minutes before recording. Recordings were made in the presence of a recording solution $(126 \mathrm{mM} \mathrm{NaCl}, 26$ $\mathrm{mM}, \mathrm{NaHCO}_{3}, 2.8 \mathrm{mM} \mathrm{KCl}, 1.25 \mathrm{mM} \mathrm{NaH}_{2} \mathrm{PO}_{4}, 1.2 \mathrm{mM}, \mathrm{MgSO}_{4}, 2.5 \mathrm{mM} \mathrm{CaCl}_{2}, 5 \mathrm{mM}$ glucose $\mathrm{pH}$ 7.3-7.35). The pipette solution for current-clamp whole-cell recording was modified to include an intracellular dye (Alexa Fluor 488): $120 \mathrm{mM} \mathrm{K}$-gluconate, $10 \mathrm{mM}$ $\mathrm{KCl}, 10 \mathrm{mM}$ HEPES, 5 mM EGTA, 1 mM CaCl 2,1 mM MgCl 2,2 mM MgATP (pH 7.29). Epifluorescence was briefly used to target fluorescent cells, at which time the light source was switched to infrared differential interference contrast imaging to obtain the whole-cell recording (Nikon Eclipse FN-S2N equipped with a fixed stage and a QImaging optiMOS sCMOS camera). Electrophysiological signals were recorded using an Axopatch 700B amplifier (Molecular Devices), low-pass filtered at 2-5 kHz, and analyzed offline on a PC with Clampfit (Molecular Devices). Recording electrodes had resistances of 2-6 M $\Omega$ when filled with the K-gluconate internal solutions. Input resistance was assessed by measuring voltage deflection at the end of the response to hyperpolarizing rectangular current pulse steps (500 ms, from -5 to $-25 \mathrm{pA},-10$ to $-50 \mathrm{pA}$ or -20 to $-100 \mathrm{pA}$ ). Membrane potential values were not compensated to account for junction potential $(-8 \mathrm{mV})$. Cell-attached recordings were either made from 4-6 week old Htr2c-2A-iCre::tdTomato mice, or from 7 week old Htr2c-2A-iCre mice injected with AAV-DIO-EYFP. Recordings were carried out by filling pipettes with recording solution and at a holding potential of $0 \mathrm{mV}$.

Photostimulation was delivered through an Optopatcher (A-M Systems), connected to a laser source (473 nm, Laserglow), through a patch cord with an NA of 4.8. Light intensity at the end of the optic fibre was measured as 6-8.4 mW. CRACM experiments were conducted in voltage-clamp mode at $-60 \mathrm{mV}$ and $-10 \mathrm{mV}$ to detect excitatory and inhibitory postsynaptic currents respectively. 3 single light pulses $(10 \mathrm{~ms})$ were delivered $1 \mathrm{~s}$ apart by triggering a pulse generator through pClamp software.

\section{Drugs}

TTX, picrotoxin, kynurenic acid, SB216641 and mCPP were acquired from Tocris. Lidocaine, tolbutamide and CNO were acquired from Sigma. Stock solutions of tolbutamide were made by dissolution in EtOH. Stock solutions TTX, picrotoxin, kynurenic acid and SB216641 were made by dissolution in DW. Stock solutions of CNO and mCPP were made in DPBS (Sigma, D8537).

\section{Statistics}

All statistics were done using Prism 6.01 (GraphPad) software. For electrophysiology experiments, nonparametric statistical tests (two-tailed Wilcoxon signed rank test or MannWhitney test) or repeated measures ANOVA with a Greenhouse-Geisser correction was used. For electrophysiology experiments, $n$ represents the final number of recorded cells. All 
chemogenetic experiments were analysed using two-way repeated measures ANOVA, matched by time and treatment. Optogenetic experiments were analysed using two-way repeated measures ANOVA matched by photostimulation conditions. For fluorescent in situ hybridisation, data was analysed using two-tailed Mann-Whitney test or two-way ANOVA. $\mathrm{Htr} 2 \mathrm{c}^{\text {flox/Y }}$ experiments were analysed using two-way repeated measures ANOVA, matched across time. Post hoc comparisons were always done using the Bonferroni correction. We presented adjusted $\mathrm{P}$ values for post hoc comparisons in supplementary table $1 . \mathrm{N}$ represent the final number of validated healthy animals. Data distribution was assumed to be normal but this was not formally tested. Sample sizes were not predetermined, but were matched to similar literature ${ }^{19,22 .}$

\section{Reporting Summary}

Further information on research design is available in the Nature Research Reporting Summary linked to this article.

\section{Code availability}

Custom code used in this study is accessible from the corresponding author upon request.

\section{Extended Data}




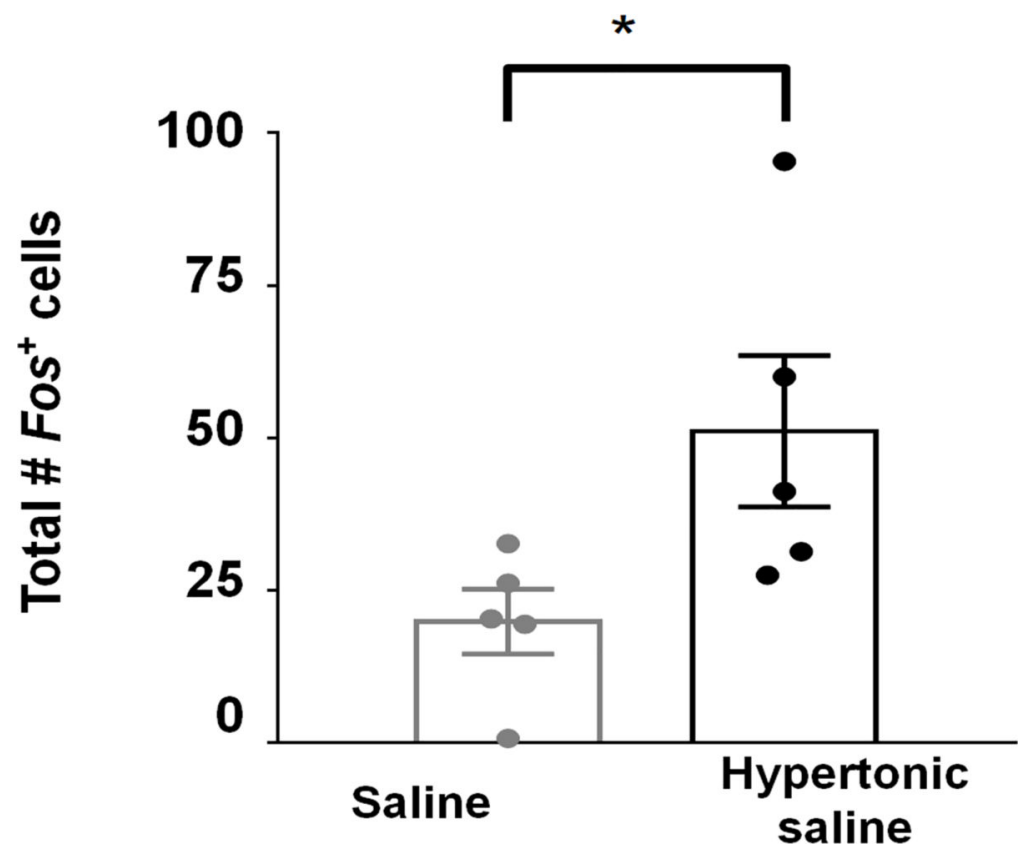

Extended Data Fig. 1: LPBN neurons respond to hypertonic saline.

Hypertonic saline-loaded mice show more Fos in the LPBN than saline-loaded controls.

Two-tailed Mann-Whitney test, Saline $\mathrm{N}=5$ mice, Hypertonic saline N =5 mice. $\mathrm{P}=0.0317$.

All data represented as mean \pm s.e.m. $* \mathrm{P}<0.05$. 
a
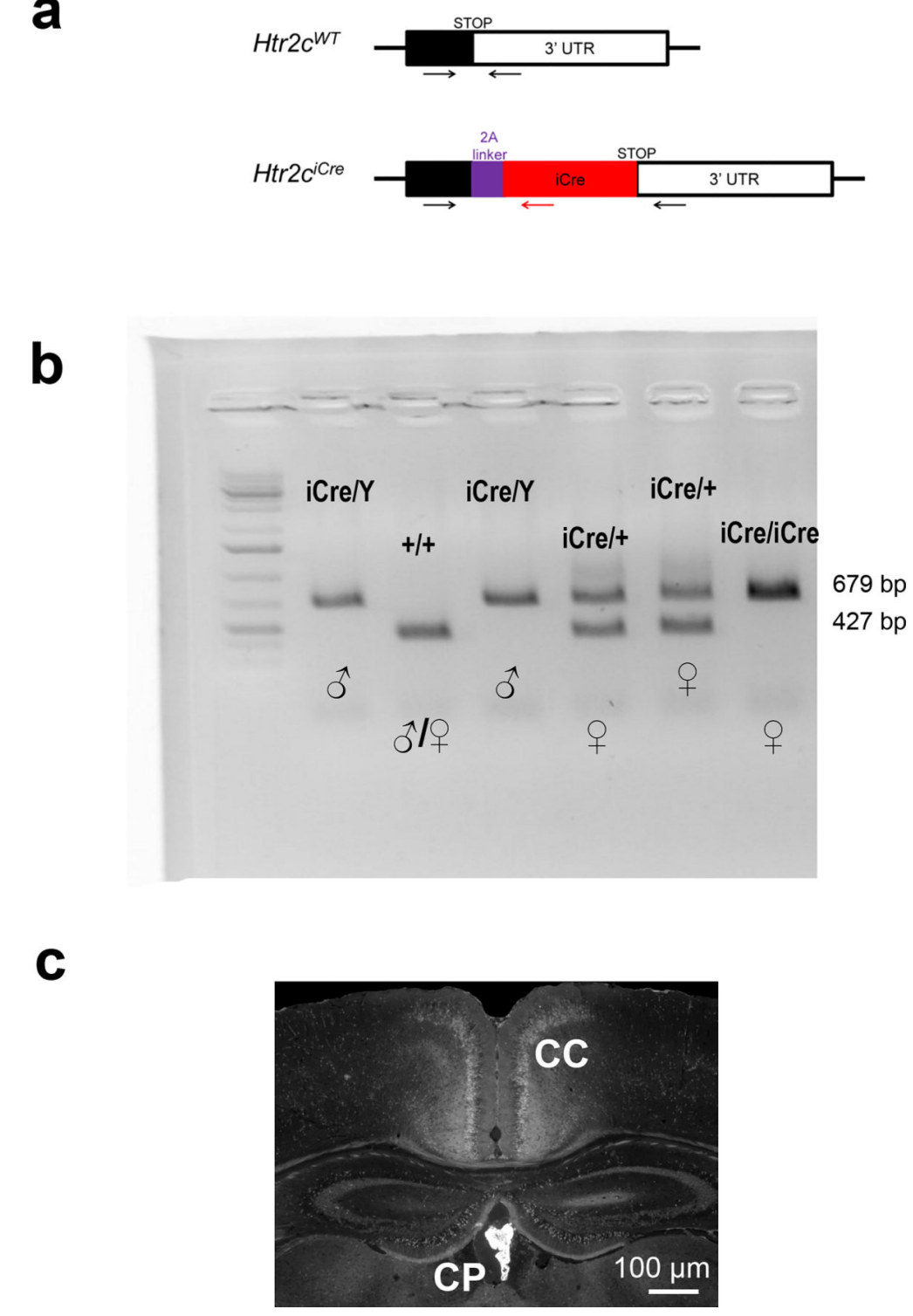

Extended Data Fig. 2: Generation of an Htr2c-2A-iCre mouse line.

(a) Htr2c-2A-iCre knock-in mice in which the coding sequences of Htr2c and iCre are linked by a viral peptide bridge $2 \mathrm{~A}$ sequence. (b) Detection of wildtype and targeted Htr $2 c$ alleles by PCR genotyping. Similar results were obtained with at least 3 independent replications. (c) Immunohistochemical analysis of Htr2c-2A-iCre activity using a tdTomato reporter. Note high levels of tdTomato expression in the choroid plexus $(\mathrm{CP})$. CC = corpus callosum. Similar results were obtained with at least 3 mice. Scale bar $=100 \mu \mathrm{m}$. 
a

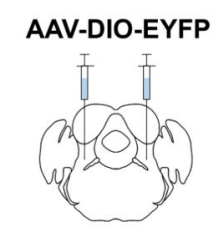

b

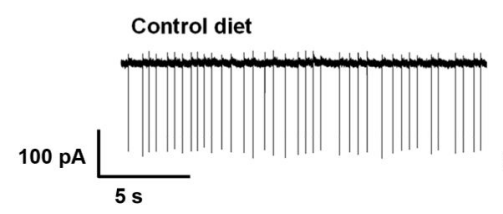

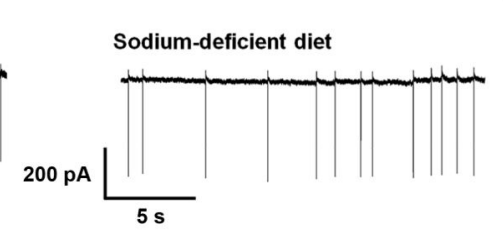

C

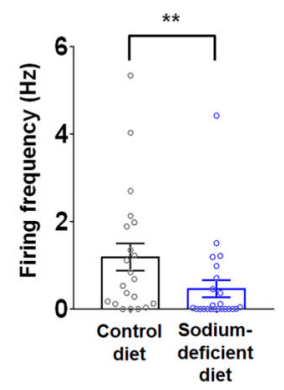

Extended Data Fig. 3: EYFP-expressing LPBN ${ }^{\mathrm{Htr} 2 \mathrm{c}}$ neurons are inhibited during sodium depletion.

(a) Cell-attached recordings taken from Htr2c-2A-iCre mice injected with AAV5-E1fa-DIOEYFP. (b) Representative cell-attached recording of LPBN ${ }^{\mathrm{Htr} 2 \mathrm{c}}$ neurons after 7 days of control diet, or 7 days of sodium-deficient diet. (c) Firing frequency of LPBN ${ }^{\mathrm{Htr} 2 \mathrm{c}}$ neurons between control diet-fed mice (left) and sodium-deficient diet-fed mice (right). Two-tailed Mann-Whitney test. Control diet $\mathrm{n}=21$ cells, sodium-deficient diet $\mathrm{n}=24$ cells. Control diet $1.2 \pm 0.3 \mathrm{~Hz}$, Sodium-deficient diet $0.4 \pm 0.2 \mathrm{~Hz}, \mathrm{P}=0.007$. All data represented as mean \pm s.e.m. $* * \mathrm{P}<0.01$. 
a

\section{AAV-DIO-mCherry}

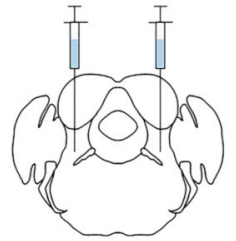

Htr2c-2A-iCre mice

b

Sodium depletion - Two-bottle assay
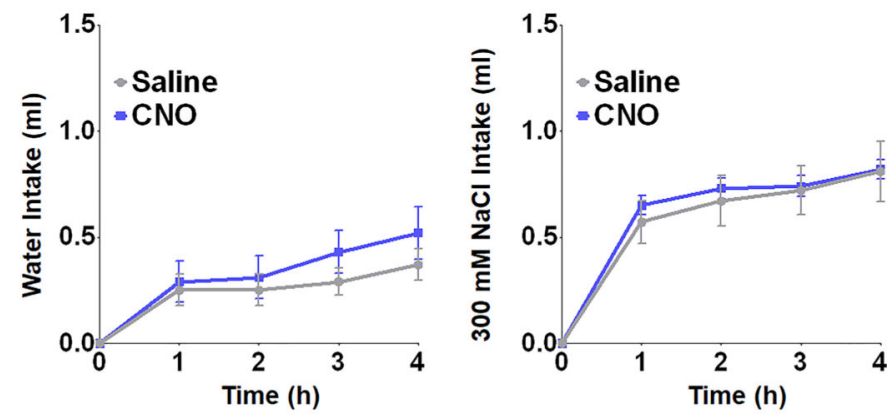

C

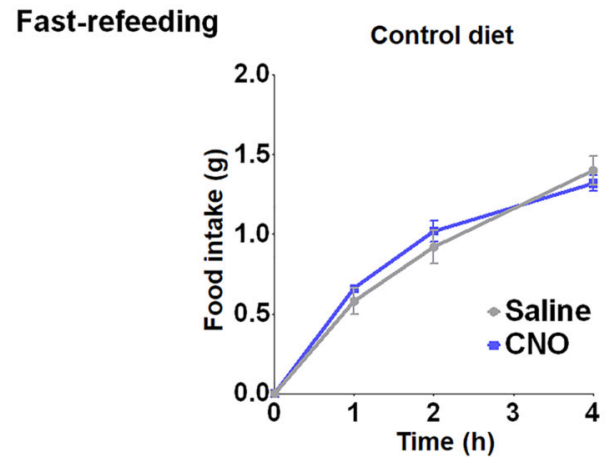

Extended Data Fig. 4: CNO injections in AAV-DIO-mCherry-injected controls do not affect food intake, water intake or $300 \mathrm{mM} \mathrm{NaCl}$ intake.

(a) Htr2c-2A-iCre mice injected with AAV2-hSyn-DIO-mCherry showed no changes in food intake, body weight or $300 \mathrm{mM} \mathrm{NaCl}$ intake. (b) No changes in water intake or 300 $\mathrm{mM} \mathrm{NaCl}$ intake during sodium depletion. $\mathrm{N}=5$ mice. Water intake during sodium depletion: Two-Way Repeated Measures ANOVA: time $(\mathrm{F}(4,16)=20.52, \mathrm{P}<0.0001)$, treatment $(\mathrm{F}(1,4)=0.5421, \mathrm{P}=0.5024)$, interaction $(\mathrm{F}(4,16)=0.6448, \mathrm{P}=0.6385) .300$ $\mathrm{mM} \mathrm{NaCl}$ intake during sodium depletion: Two-Way Repeated Measures ANOVA: time $(\mathrm{F}(4,16)=108.1, \mathrm{P}<0.0001)$, treatment $(\mathrm{F}(1,4)=0.1128, \mathrm{P}=0.7538)$, interaction $(\mathrm{F}(4,16)$ $=0.3142, \mathrm{P}=0.8643)$. (c) No changes in food intake or body weight when using a control diet. $\mathrm{N}=5$ mice. Control diet food intake: Two-Way Repeated Measures ANOVA: time $(\mathrm{F}(3,12)=223.9, \mathrm{P}<0.0001)$, treatment $(\mathrm{F}(1,4)=0.2222, \mathrm{P}=0.6619)$, interaction $(\mathrm{F}(3,12)$ $=2.689, \mathrm{P}=0.0924)$. All data represented as mean \pm s.e.m. 
a

\section{AAV-DIO-hM3Dq-mCherry}

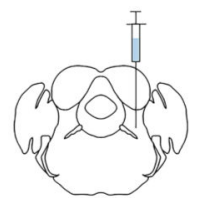

Htr2c-2A-iCre mice

b

Dehydration - Two-bottle assay
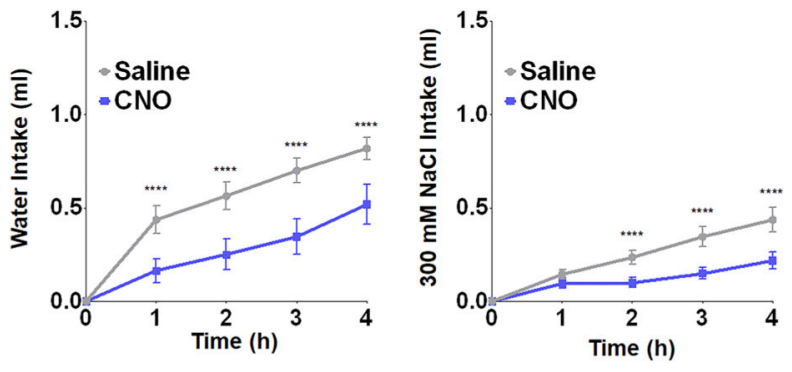

C

Fast-refeeding
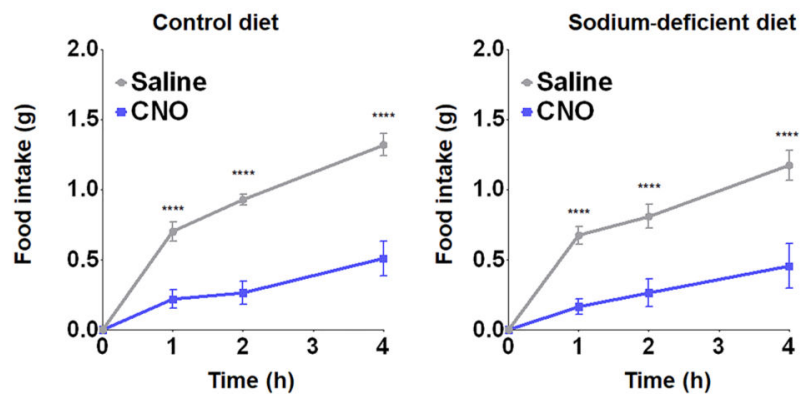

Extended Data Fig. 5: LPBN $^{\mathrm{Htr2c}}$ neuron activation can cause non-sodium related effects.

(a) Unilateral injection of AAV5-hSyn-DIO-hM3Dq into the LPBN of Htr2c-2A-iCre mice. (b) Activation of $\mathrm{LPBN}^{\mathrm{Htr} 2 \mathrm{c}}$ neurons decreased water and $300 \mathrm{mM} \mathrm{NaCl}$ intake during dehydration in a two-bottle choice assay. $\mathrm{N}=11$. Water intake during dehydration: Two-Way Repeated Measures ANOVA: time $(\mathrm{F}(4,40)=67.06, \mathrm{P}<0.0001)$, treatment $(\mathrm{F}(1,10)=$ $8.707, \mathrm{P}=0.0145)$, interaction $(\mathrm{F}(4,40)=6.329, \mathrm{P}=0.0005)$. Post hoc tests using the Bonferroni correction. $300 \mathrm{mM} \mathrm{NaCl}$ intake during dehydration: Two-Way Repeated Measures ANOVA: time $(\mathrm{F}(4,40)=31.38, \mathrm{P}<0.0001)$, treatment $(\mathrm{F}(1,10)=17.76 \mathrm{P}=$ $0.0018)$, interaction $(\mathrm{F}(4,40)=14.06 \mathrm{P}=0.0001)$. (c) Activation of $\mathrm{LPBN}^{\mathrm{Htr} 2 \mathrm{c}}$ neurons decreased food during a fast refeeding regardless of sodium content. $\mathrm{N}=11$. Control diet food intake (left): Two-Way Repeated Measures ANOVA: time $(\mathrm{F}(3,30)=111.0, \mathrm{P}<$ $0.0001)$, treatment $(\mathrm{F}(1,10)=51.2, \mathrm{P}<0.0001)$, interaction $(\mathrm{F}(3,30)=32.00, \mathrm{P}<0.0001)$. Sodium-deficient diet food intake (right): Two-Way Repeated Measures ANOVA: time $(\mathrm{F}(3,30)=50.59, \mathrm{P}<0.0001)$, treatment $(\mathrm{F}(1,10)=27.74, \mathrm{P}=0.0004)$, interaction $(\mathrm{F}(3,30)$ $=18.81, \mathrm{P}<0.0001)$. All post hoc tests using the Bonferroni correction. All data represented as mean \pm s.e.m. $* * * * \mathrm{P}<0.0001$. 
a

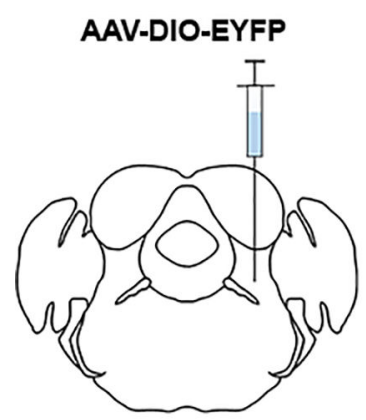

Htr2c-2A-iCre mice

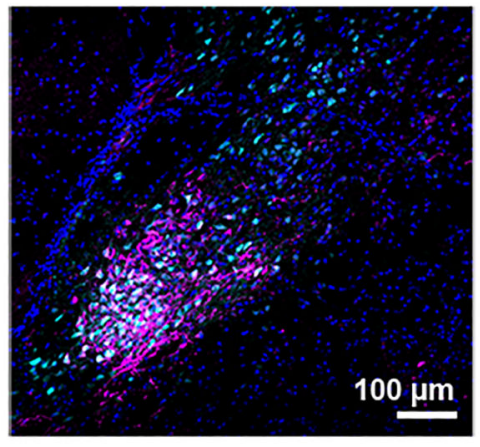

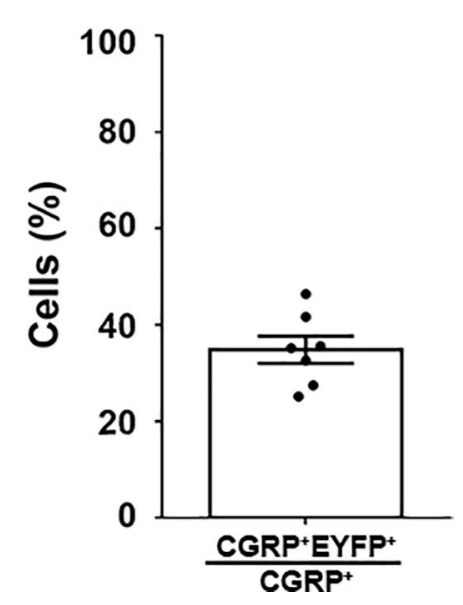

Extended Data Fig. 6: LPBN ${ }^{\mathrm{Htr} 2 \mathrm{c}}$ neurons colocalise with CGRP.

(a) Schematic of experiment. Unilateral injection of AAV5-EF1a-DIO -EYFP into the LPBN of Htr2c-2A-iCre mice to visualise LPBN ${ }^{H t r 2 c}$ neurons (left). Colocalisation of EYFP labelled LPBN ${ }^{\mathrm{Htr} 2 \mathrm{c}}$ neurons with CGRP (right). Cyan $=\mathrm{EYFP}$, Magenta $=\mathrm{CGRP}$, Blue $=$ DAPI. Scale bar $=100 \mu \mathrm{m}$. (b) Estimation of colocalisation between LPBNHtr2c neurons and CGRP neurons. 3 slices taken from each mice. $\mathrm{N}=7$ mice. 


\section{a}
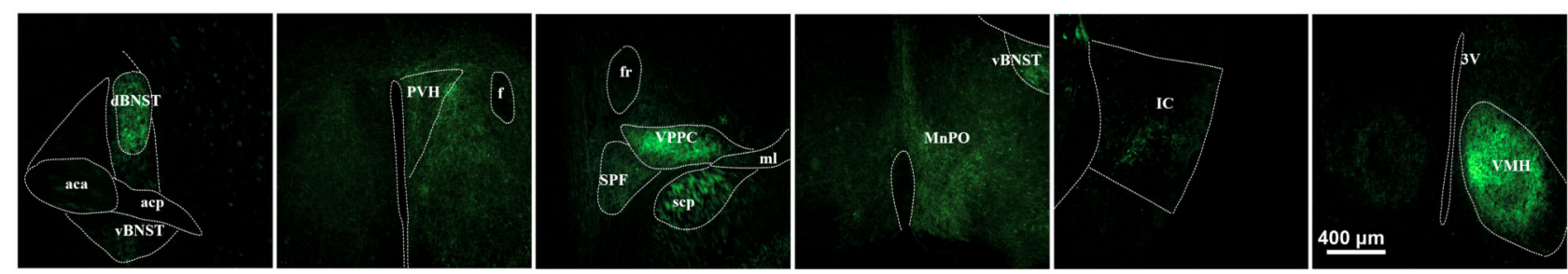

b

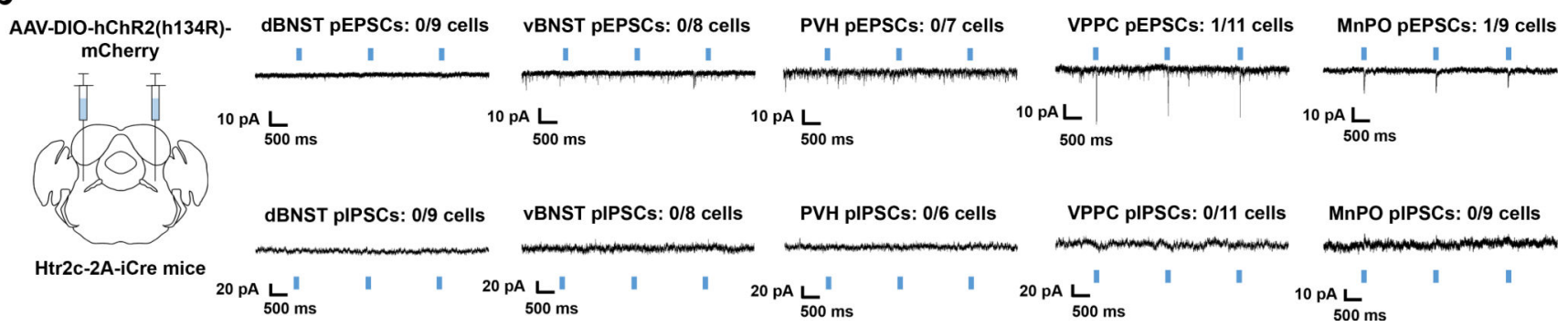

Extended Data Fig. 7. Downstream circuitry of LPBN ${ }^{\mathrm{Htr} 2 \mathrm{c}}$ neurons.

(a) Axonal projections visualised by unilateral injection of AAV5-EF1a-DIO-EYFP into the LPBN of Htr2c-2A-iCre mice. aca = anterior commissure (anterior part), acp = anterior commissure (posterior part), $\mathrm{dBNST}=$ bed nucleus of the stria terminalis (lateral division), $\mathrm{fr}=$ fasciculus retroflexus, $\mathrm{ml}=$ medial lemniscus, $\mathrm{MnPO}=$ median preoptic nucleus, $\mathrm{opt}=$ optic tract, $\mathrm{PVH}=$ paraventricular nucleus of the hypothalamus, $\mathrm{scp}=$ superior cerebellar peduncle, SPF = subparafascicular thalamus, st $=$ stria terminalis, $\mathrm{vBNST}=$ bed nucleus of the stria terminalis (ventral part), VPPC $=$ ventral posterior thalamus (parvicellular part). Scale bar $=400 \mu \mathrm{m} . \mathrm{N}=7$ mice. (b) Schematic of experiment. Bilateral injection of AAV2DIO-hChR2 (H134R)-p2A-mCherry into the LPBN of Htr2c-2A-iCre mice (left). Voltageclamp recordings taken at downstream sites (traces on the right). Blue rectangles indicate times of photostimulation. 


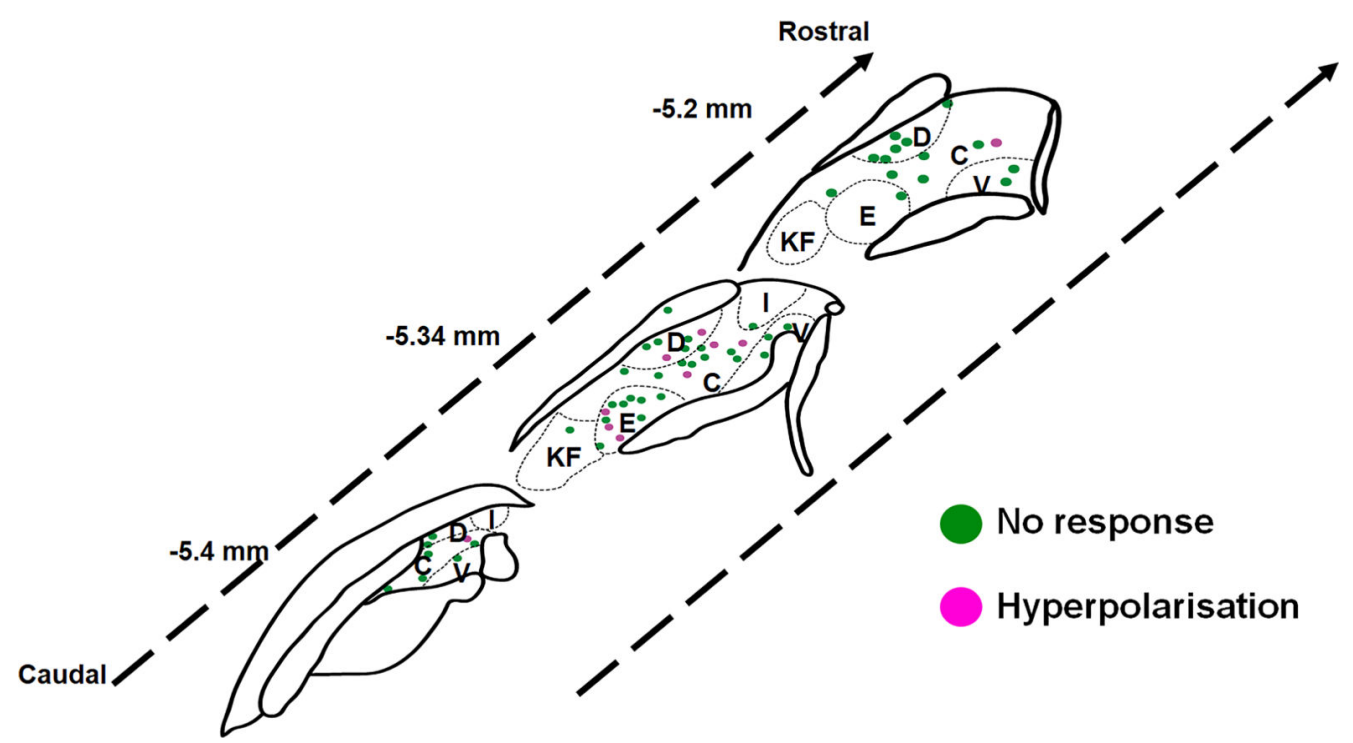

Extended Data Fig. 8: Illustration showing the approximate spatial distribution of mCPPresponsive neurons within the $L P B N$.

$\mathrm{C}=$ central LPBN, D = dorsal LPBN, E = external LPBN, I = internal LPBN, KF = Kolliker's Fuse, V = ventral LPBN. 
a

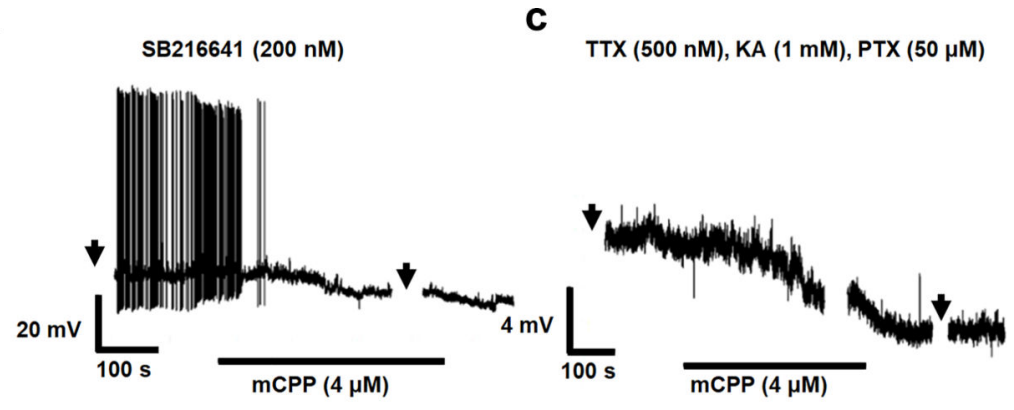

b

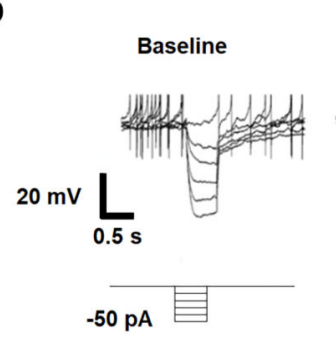

d

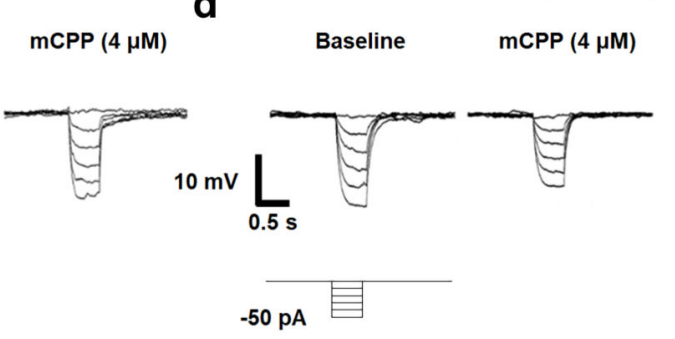

g e

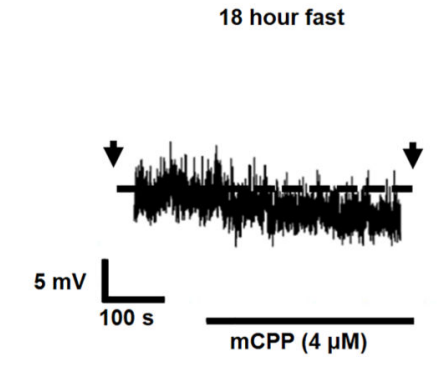

f

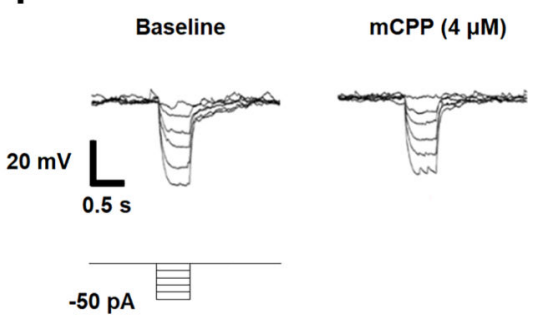

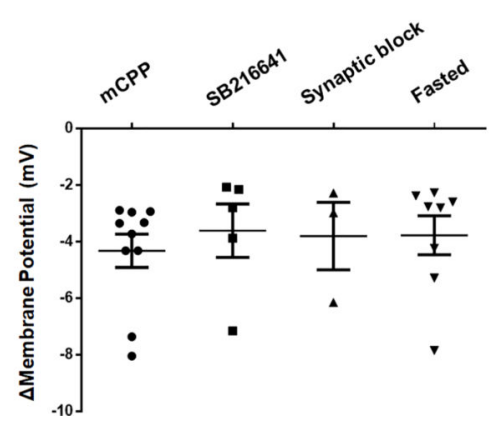

Extended Data Fig. 9: Hyperpolarisation of $\mathrm{LPBN}^{\mathrm{Htr} 2 \mathrm{c}}$ neurons is not dependent on Htr1b and is postsynaptic.

(a) Representative current clamp recording of an $\mathrm{LPBN}^{\mathrm{Htr} 2 \mathrm{c}}$ neuron pre-treated with SB216641 (200 nM). Hyperpolarisation in response to mCPP persists in presence of SB216641. Arrows indicate time at which current steps were applied. (b) Voltage deflections in response to hyperpolarising currents from the same neuron, showing decreased input resistance in response to $\mathrm{mCPP}$. Current steps in trace made in $10 \mathrm{pA}$ increments from -50 pA to 0 pA. (c) Representative current clamp recording of an $\mathrm{LPBN}^{\mathrm{Ht} 2 \mathrm{c}}$ neuron pre-treated with TTX (500 nM), kynurenic acid (KA, $1 \mathrm{mM}$ ) and picrotoxin (PTX, $50 \mu \mathrm{M})$, showing hyperpolarisation in response to $\mathrm{mCPP}$. Arrows indicate time at which current steps were applied. (d) Voltage deflections in response to hyperpolarising currents from the same neuron, showing decreased input resistance in response to mCPP. Current steps in trace made in $10 \mathrm{pA}$ increments from $-50 \mathrm{pA}$ to $0 \mathrm{pA}$. (e) Representative current clamp recording of an LPBN ${ }^{\mathrm{Htr} 2 \mathrm{c}}$ neuron from a fasted mouse (18 hours), showing hyperpolarisation in response to mCPP. Arrows indicate time at which current steps were applied. (f) Voltage deflections in response to hyperpolarising currents from the same neuron, showing decreased input resistance in response to mCPP. Current steps in trace made in $10 \mathrm{pA}$ increments from $-50 \mathrm{pA}$ to $0 \mathrm{pA}$. (g) Graph summarising change in membrane potential in response to mCPP under conditions tested. Neither pre-treatment with SB216641, Synaptic 
blockers nor recordings from fasted mice changed the magnitude of response to $\mathrm{mCPP}$. $m$ CPP $n=10$ cells, SB216641 $n=5$ cells, Synaptic block $n=3$ cells, Fasted $n=8$ cells. Data represented as mean \pm s.e.m 
a

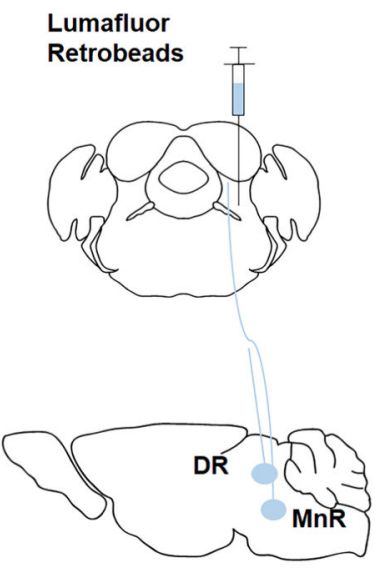

b
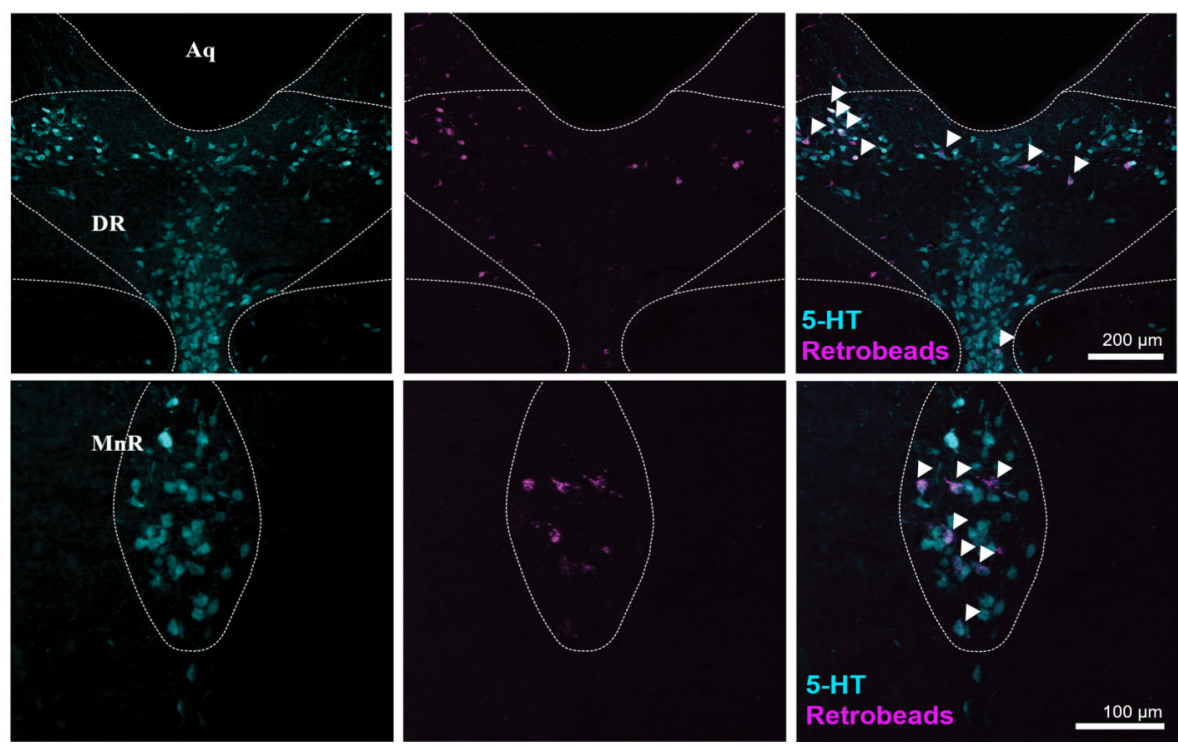

Extended Data Fig. 10: Serotoninergic projections to the LPBN.

(a) Schematic of experiment. Unilateral injection of Lumafluor retrobeads into the LPBN of wildtype mice to visualise upstream neurons. (b) Arrows indicate colocalised cells. Aq = aqueduct, $\mathrm{DR}=$ dorsal raphe. Scale bar $=200 \mu \mathrm{m} . \mathrm{N}=6$ mice (upper). $\mathrm{MnR}=$ median raphe. Scale bar $=100 \mu \mathrm{m} . \mathrm{N}=6$ mice (lower).

\section{Supplementary Material}

Refer to Web version on PubMed Central for supplementary material.

\section{Acknowledgements}

We thank Dr. Greg S. B. Suh (KAIST) for helpful comments on the manuscript, Dr. Seung-Hee Lee (KAIST) for technical help with viral tracing experiments, and Dr. Daesoo Kim (KAIST) for technical help with imaging. This work was supported by grants from Samsung Science \& Technology Foundation (SSTF-BA1901-11 to J.-W.S.), KAIST Future Systems Health Care Project (to J.-W.S.), American Heart Association (16SDG27260001 to C.L.), and National Institute of Health (R01 DK114036 to C.L. and R01 DK100699 to K.W.W.). S.P. was supported in part by stipends from the national research foundation of Korea (NRF-2015M3A9E7029177 and NRF-2016R1C1B2006614 to J.-W.S.).

\section{References}

1. Wagman W (1963). Sodium chloride deprivation: development of sodium chloride as a reinforcement. Science, 140 (3574), 1403-1404. [PubMed: 13998205]

2. Matsuda Takashi, Hiyama Takeshi Y., Niimura Fumio, Matsusaka Taiji, Fukamizu Akiyoshi, Kobayashi Kenta, Kobayashi Kazuto, and Noda Masaharu (2017). Distinct neural mechanisms for the control of thirst and salt appetite in the subfornical organ. Nature neuroscience, 20(2), 230. [PubMed: 27991901]

3. Jarvie BC, and Palmiter RD (2017). HSD2 neurons in the hindbrain drive sodium appetite. Nature neuroscience, 20(2), 167. [PubMed: 27918529]

4. Resch JM, Fenselau H, Madara JC, Wu C, Campbell JN, Lyubetskaya A, Brian A Dawes et al. (2017). Aldosterone-sensing neurons in the NTS exhibit state-dependent pacemaker activity and 
drive sodium appetite via synergy with angiotensin II signaling. Neuron, 96(1), 190-206. [PubMed: 28957668]

5. Oka Y, Butnaru M, von Buchholtz L, Ryba NJ, and Zuker CS (2013). High salt recruits aversive taste pathways. Nature, 494(7438), 472. [PubMed: 23407495]

6. de Oliveira LB, Callera JC, De Luca LA Jr, Colombari DS, and Menani JV (2007). GABAergic mechanisms of the lateral parabrachial nucleus on sodium appetite. Brain research bulletin, 73(4-6), 238-247. [PubMed: 17562389]

7. De Gobbi JI, Beltz TG, Johnson RF, Menani JV, Thunhorst RL, \& Johnson AK (2009). Non-NMDA receptors in the lateral parabrachial nucleus modulate sodium appetite. Brain research, 1301, 44-51. [PubMed: 19747457]

8. Johnson AK, and Thunhorst RL (1997). The neuroendocrinology of thirst and salt appetite: visceral sensory signals and mechanisms of central integration. Frontiers in neuroendocrinology, 18(3), 292353. [PubMed: 9237080]

9. Scalera G, Spector AC, and Norgren R (1995). Excitotoxic lesions of the parabrachial nuclei prevent conditioned taste aversions and sodium appetite in rats. Behavioral neuroscience, 109(5), 997. [PubMed: 8554723]

10. Geerling JC, Stein MK, Miller RL, Shin JW, Gray PA, and Loewy AD (2011). FoxP2 expression defines dorsolateral pontine neurons activated by sodium deprivation. Brain research, 1375, 19-27. [PubMed: 21108936]

11. Castro L, Athanazio R, Barbetta M, Ramos AC, Angelo AL, Campos I, Varjão B, Ferreira H, Fregoneze J and e Silva EDC (2003). Central 5-HT2B/2C and 5-HT3 receptor stimulation decreases salt intake in sodium-depleted rats. Brain research, 981(1-2), 151-159. [PubMed: 12885436]

12. Gentili L, Saija A, Luchetti G, and Massi M (1991). Effect of the 5-HT2 antagonist ketanserin on salt appetite in the rat. Pharmacology Biochemistry and Behavior, 39(1), 171-176.

13. Menani JV, Thunhorst RL, and Johnson AK (1996). Lateral parabrachial nucleus and serotonergic mechanisms in the control of salt appetite in rats. American Journal of Physiology-Regulatory, Integrative and Comparative Physiology, 270(1), R162-R168.

14. De Gobbi JIF, Martinez G, Barbosa SP, Beltz TG, De Luca LA Jr, Thunhorst RL, Johnson AK, and Vanderlei Menani J. 5-HT2 and 5-HT3 receptors in the lateral parabrachial nucleus mediate opposite effects on sodium intake. Neuroscience, 146(4), 1453-1461.

15. Yamamoto T, Shimura T, Sako N, Sakai N, Tanimizu T, and Wakisaka S (1993). c-Fos expression in the parabrachial nucleus after ingestion of sodium chloride in the rat. Neuroreport, 4(11), $1223-$ 1226. [PubMed: 8219018]

16. Geerling JC, and Loewy AD (2007). Sodium deprivation and salt intake activate separate neuronal subpopulations in the nucleus of the solitary tract and the parabrachial complex. Journal of Comparative Neurology, 504(4), 379-403. [PubMed: 17663450]

17. Ryan PJ, Ross SI, Campos CA, Derkach VA, and Palmiter RD (2017). Oxytocin-receptorexpressing neurons in the parabrachial nucleus regulate fluid intake. Nature neuroscience, 20(12), 1722. [PubMed: 29184212]

18. Donnelly ML, Luke G, Mehrotra A, Li X, Hughes LE, Gani D, and Ryan MD (2001). Analysis of the aphthovirus $2 \mathrm{~A} / 2 \mathrm{~B}$ polyprotein 'cleavage' mechanism indicates not a proteolytic reaction, but a novel translational effect: a putative ribosomal 'skip'. Journal of General Virology, 82(5), 10131025. [PubMed: 11297676]

19. Carter ME, Soden ME, Zweifel LS, and Palmiter RD (2013). Genetic identification of a neural circuit that suppresses appetite. Nature, 503(7474), 111. [PubMed: 24121436]

20. Campos CA, Bowen AJ, Han S, Wisse BE, Palmiter RD, and Schwartz MW (2017). Cancerinduced anorexia and malaise are mediated by CGRP neurons in the parabrachial nucleus. Nature neuroscience, 20(7), 934. [PubMed: 28581479]

21. Campos CA, Bowen AJ, Schwartz MW, and Palmiter RD (2016). Parabrachial CGRP neurons control meal termination. Cell metabolism, 23(5), 811-820. [PubMed: 27166945]

22. Garfield AS, Li C, Madara JC, Shah BP, Webber E, Steger JS, Campbell JN, Gavrilova O, Lee CE, Olson DP, Elmquist JK, Tannous BA, Krashes MJ and Lowell BB (2015) A neural basis for 
melanocortin-4 receptor-regulated appetite. Nature neuroscience, 18(6), 863. [PubMed: 25915476]

23. Stricker EM, \& Verbalis JG (1987). Central inhibitory control of sodium appetite in rats: correlation with pituitary oxytocin secretion. Behavioral neuroscience, 101(4), 560. [PubMed: 2820437]

24. Geerling JC, Chimenti PC, and Loewy AD (2008). Phox2b expression in the aldosterone-sensitive HSD2 neurons of the NTS. Brain research, 1226, 82-88. [PubMed: 18620340]

25. Kang BJ, Chang DA, Mackay DD, West GH, Moreira TS, Takakura AC, Gwilt JM, Guyenet PG and Stornetta RL (2007). Central nervous system distribution of the transcription factor Phox $2 b$ in the adult rat. Journal of Comparative Neurology, 503(5), 627-641. [PubMed: 17559094]

26. Hashimoto K, Obata K, and Ogawa H (2009). Characterization of parabrachial subnuclei in mice with regard to salt tastants: possible independence of taste relay from visceral processing. Chemical senses, 34(3), 253-267. [PubMed: 19179538]

27. Biondolillo JW, Williams LA, and King MS (2009). Blocking glutamate receptors in the waist area of the parabrachial nucleus decreases taste reactivity behaviors in conscious rats. Chemical senses, 34(3), 221-230. [PubMed: 19174448]

28. Chandrashekar J, Kuhn C, Oka Y, Yarmolinsky DA, Hummler E, Ryba NJ, \& Zuker CS (2010). The cells and peripheral representation of sodium taste in mice. Nature, 464(7286), 297. [PubMed: 20107438]

29. Zardetto-Smith AM, Beltz TG, and Johnson AK (1994). Role of the central nucleus of the amygdala and bed nucleus of the stria terminalis in experimentally-induced salt appetite. Brain research, 645(1-2), 123-134. [PubMed: 8062074]

30. Galaverna O, De Luca LA Jr, Schulkin J, Yao SZ, and Epstein AN (1992). Deficits in NaCl ingestion after damage to the central nucleus of the amygdala in the rat. Brain research bulletin, 28(1), 89-98. [PubMed: 1540849]

31. Dong HW, Petrovich GD, \& Swanson LW (2001). Topography of projections from amygdala to bed nuclei of the stria terminalis. Brain research reviews, 38(1-2), 192-246. [PubMed: 11750933]

32. Dong HW, Petrovich GD, Watts AG, \& Swanson LW (2001). Basic organization of projections from the oval and fusiform nuclei of the bed nuclei of the stria terminalis in adult rat brain. Journal of Comparative Neurology, 436(4), 430-455. [PubMed: 11447588]

33. Lee S, Augustine V, Zhao Y, Ebisu H, Ho B, Kong D, \& Oka Y (2019). Chemosensory modulation of neural circuits for sodium appetite. Nature, 568(7750), 93-97. [PubMed: 30918407]

34. Chen Y, Baez M, and Yu L (1994). Functional coupling of the 5-HT2C serotonin receptor to G proteins in Xenopus oocytes. Neuroscience letters, 179(1-2), 100-102. [PubMed: 7531308]

35. Lucaites VL, Nelson DL, Wainscott DB, and Baez M (1996). Receptor subtype and density determine the coupling repertoire of the 5-HT2 receptor subfamily. Life sciences, 59(13), 10811095. [PubMed: 8809227]

36. Kurachi Y, Tung RT, Ito H, and Nakajima T (1992). G protein activation of cardiac muscarinic K+ channels. Progress in neurobiology, 39(3), 229-246. [PubMed: 1502337]

37. Petrov T, Krukoff TL, and Jhamandas JH (1992). The hypothalamic paraventricular and lateral parabrachial nuclei receive collaterals from raphe nucleus neurons: a combined double retrograde and immunocytochemical study. Journal of Comparative Neurology, 318(1), 18-26. [PubMed: 1583154]

38. Bang SJ, Jensen P, Dymecki SM, and Commons KG (2012). Projections and interconnections of genetically defined serotonin neurons in mice. European Journal of Neuroscience, 35(1), 85-96. [PubMed: 22151329]

39. Smits JF, van Essen H, and Struyker-Boudier HA (1978). Serotonin-mediated cardiovascular responses to electrical stimulation of the raphe nuclei in the rat. Life sciences, 23(2), 173-178. [PubMed: 150481]

\section{Methods-only References}

40. Berglund ED, Liu C, Sohn J-W, Liu T, Kim MH, Lee CE, Vianna CR, Williams KW, Xu Y, and Elmquist JK (2013). Serotonin 2C receptors in pro-opiomelanocortin neurons regulate energy and 
glucose homeostasis. The Journal of clinical investigation, 123(12), 5061-5070. [PubMed: 
a

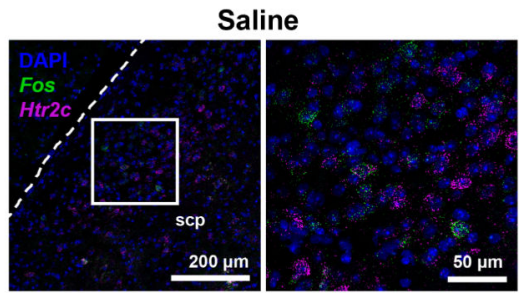

d

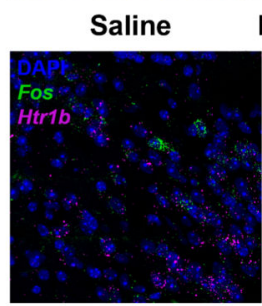

g
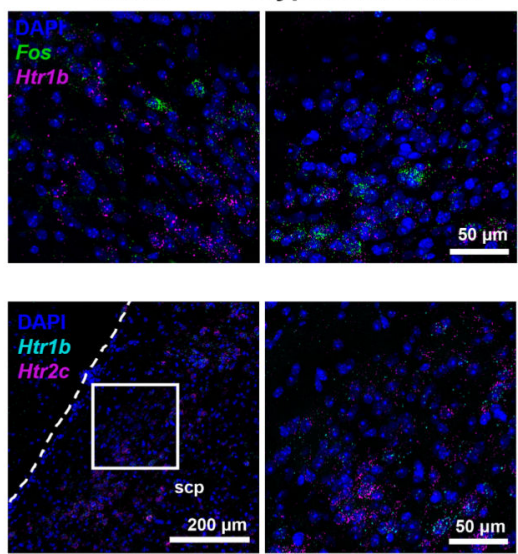

b

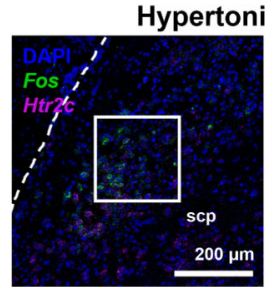

e Hypertonic saline

\section{h}
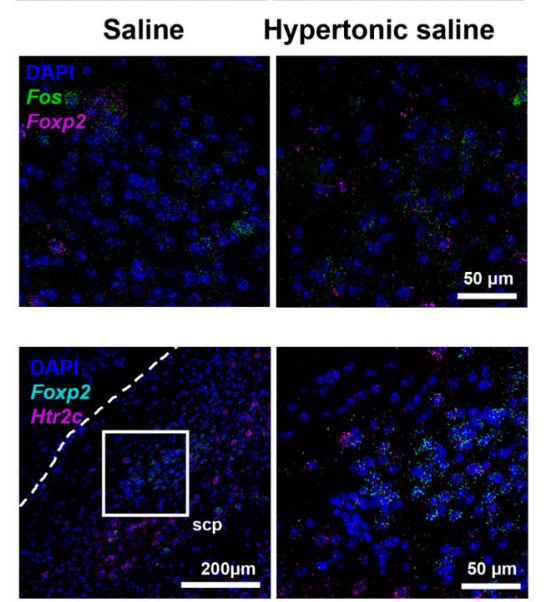

j

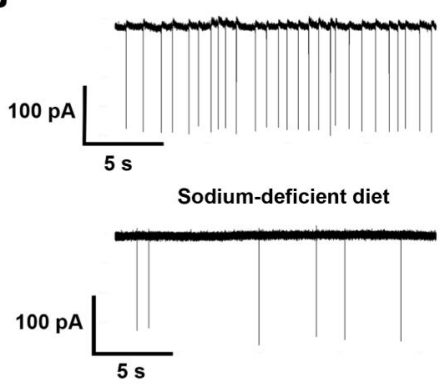

k

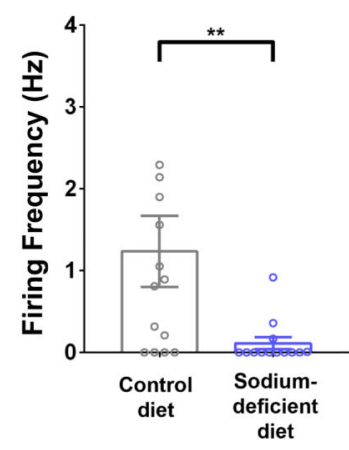

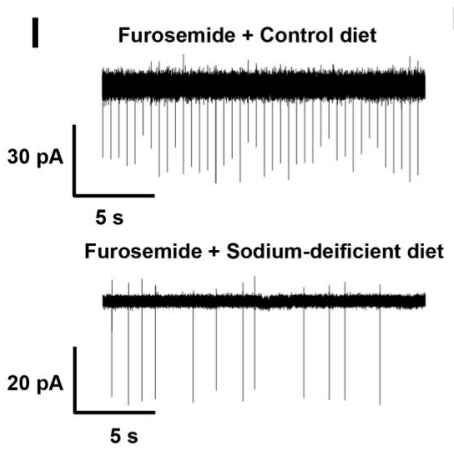

C
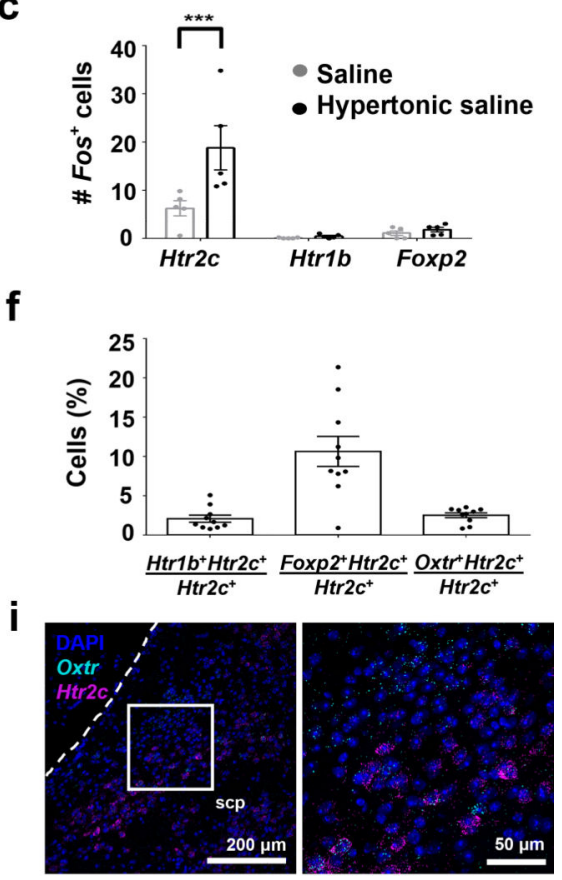

m

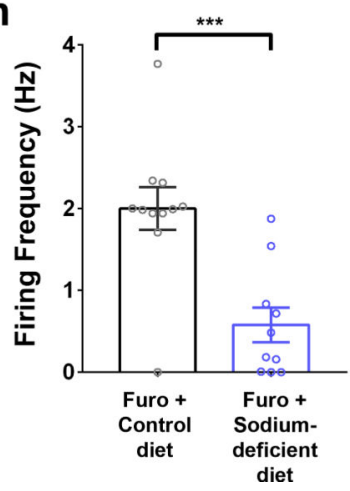

Figure 1. LPBN ${ }^{\mathrm{Htr} 2 \mathrm{c}}$ neurons are regulated by bodily sodium content.

(a) Colocalisation of Fos and Htr2c in the LPBN after gastric loading of saline. Low magnification picture (left), higher magnification of area inside white box (right). Scale bars, left $=200 \mu \mathrm{m}$, right $=50 \mu \mathrm{m}$. Dashed lines indicate ventral spinocerebellar tract. $\mathrm{scp}=$ superior cerebellar peduncle. (b) Colocalisation of Fos and Htr2c in the LPBN after gastric loading of hypertonic saline. Low magnification picture (left), higher magnification of area inside white box (right). Scale bars, left $=200 \mu \mathrm{m}$, right $=50 \mu \mathrm{m}$. (c) Quantification of Fos expressing neurons that co-express Htr2c, Htr1b or Foxp2. Data points represent average number of cells counted per slice for each animal. Saline $\mathrm{N}=5$ mice, Hypertonic saline N $=5$ mice. Two-Way ANOVA: treatment $(\mathrm{F}(2,24)=22.72, \mathrm{P}<0.0001)$, gene $(\mathrm{F}(1,24)=$ $7.671, \mathrm{P}=0.0107)$, interaction $(\mathrm{F}(2,24)=5.949 \mathrm{P}=0.0080)$. All post hoc tests done using the Bonferroni correction, $\mathrm{P}=0.000552$. (d) Colocalisation of Fos with Htr $1 b$ in the LPBN after gastric loading of saline or hypertonic saline. Scale bar $=50 \mu \mathrm{m}$. (e) Colocalisation of Fos with Foxp2 in the LPBN after gastric loading of saline or hypertonic saline. Scale bar = $50 \mu \mathrm{m}$. (f) Quantification of percentage of Htr2c neurons that coexpress Htr1b, Foxp2 or 
Oxtr. Data points represent average percentages counted per slice for each animal. $\mathrm{N}=10$ mice. (g) Colocalisation of Htr $1 b$ with Htr2c in the LPBN. Low magnification picture (left), higher magnification of area inside white box (right). Scale bars, left $=200 \mu \mathrm{m}$, right $=50$ $\mu \mathrm{m}$. (h) Colocalisation of Foxp2 with Htr2c in the LPBN. Low magnification picture (left), higher magnification of area inside white box (right). Scale bars, left $=200 \mu \mathrm{m}$, right $=50$ $\mu \mathrm{m}$. (i) Colocalisation of Oxtr with Htr2c in the LPBN. Low magnification picture (left), higher magnification of area inside white box (right). Scale bars, left $=200 \mu \mathrm{m}$, right $=50$ $\mu \mathrm{m}$. (j) Representative cell-attached recording of an $\mathrm{LPBN}^{\mathrm{Htr} 2 \mathrm{c}}$ neuron after 7-8 days of control diet (upper), or 7-8 days of sodium-deficient diet (lower). (k) Firing frequency of $\mathrm{LPBN}^{\mathrm{Htr} 2 \mathrm{c}}$ neurons between control diet-fed mice (left) and sodium-deficient diet-fed mice (right). Two-tailed Mann-Whitney test. Control diet $\mathrm{n}=14$ cells, sodium-deficient $\operatorname{diet} \mathrm{n}=$ 13 cells. Control diet $1.2 \pm 0.4 \mathrm{~Hz}$, Sodium-deficient diet $0.1 \pm 0.1 \mathrm{~Hz} . \mathrm{P}=0.008$. (l)

Representative cell-attached recording of an $\mathrm{LPBN}^{\mathrm{Htr} 2 \mathrm{c}}$ neuron after furosemide and control diet treatment (upper) or furosemide and sodium-deficient diet treatment (lower). (m) Firing frequency of $\mathrm{LPBN}^{\mathrm{Htr} 2 \mathrm{c}}$ neurons between control diet fed mice (left) and sodium-deficient diet fed mice (right). Two-tailed Mann-Whitney test. Furosemide + control diet $\mathrm{n}=11$ cells, furosmide + sodium-deficient diet $\mathrm{n}=10$ cells. Furosemide + control diet $2.0 \pm 0.3 \mathrm{~Hz}$, furosemide + sodium-deficient diet $0.6 \pm 0.2 \mathrm{~Hz} . \mathrm{P}=0.0007$. All data represented as mean \pm s.e.m. $* * \mathrm{P}<0.01, * * * \mathrm{P}<0.001$. 
a

Sodium depletion protocol

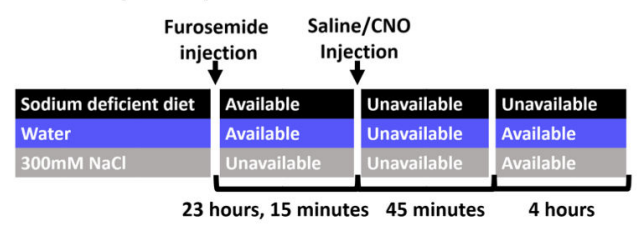

b

AAV-DIO-hM3Dq-mCherry

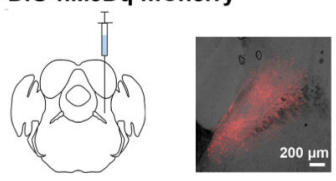

Htr2c-2A-iCre mice

c

d

Sodium depletion - Two-bottle assay
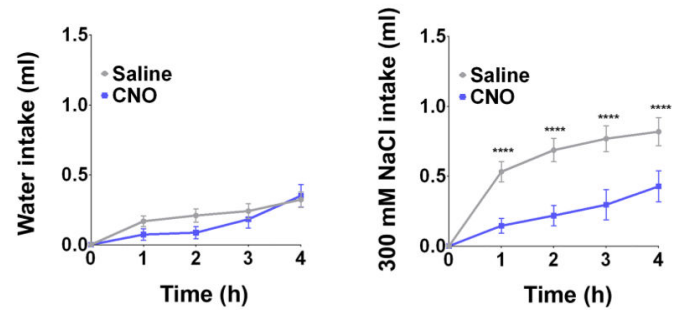

e

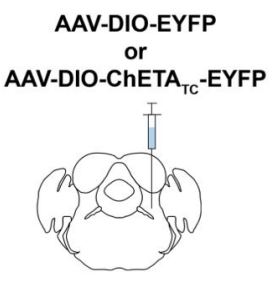

Htr2c-2A-iCre mice

g

Sodium depletion - One-bottle assay
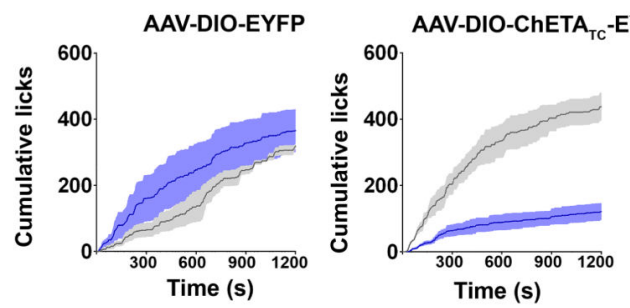

f

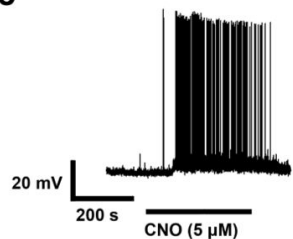

$200 \mathrm{~s} \overline{\mathrm{CNO}(5 \mu \mathrm{M})}$

- No photostimulation

- $10 \mathrm{~Hz}$ photostimulation
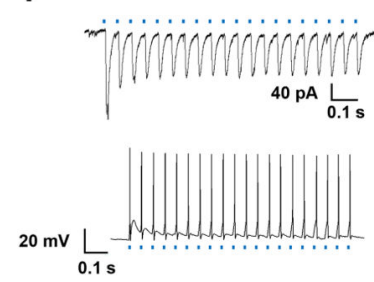

h

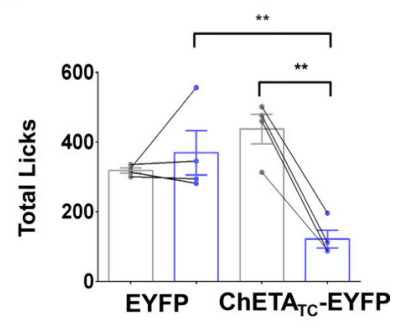

No photostimulation - $10 \mathrm{~Hz}$ photostimulation

Figure 2. Activation of LPBN ${ }^{H t r 2 c}$ neurons suppresses sodium intake.

(a) Schematic illustration showing schedule for sodium depletion. (b) Unilateral injection of AAV5-hSyn-DIO-hM3Dq-mCherry into the LPBN of Htr2c-2A-iCre mice (left).

Representative image of injection site (right). Scale bar $=200 \mu \mathrm{m}$. (c) DREADDs validated through current-clamp recordings. (d) Water intake during sodium depletion: Two-Way Repeated Measures ANOVA: time $(\mathrm{F}(4,40)=33.11, \mathrm{P}<0.0001)$, treatment $(\mathrm{F}(1,10)=$ $0.8369, \mathrm{P}=0.3818)$, interaction $(\mathrm{F}(4,40)=1.712, \mathrm{P}=0.1663) .300 \mathrm{mM} \mathrm{NaCl}$ intake during sodium depletion: Two-Way Repeated Measures ANOVA: time $(\mathrm{F}(4,40)=68.77, \mathrm{P}<$ 
$0.0001)$, treatment $(\mathrm{F}(1,10)=10.57 \mathrm{P}=0.0089)$, interaction $(\mathrm{F}(4,40)=7.546, \mathrm{P}=0.0001)$ $\mathrm{N}=11$. (e) Unilateral injection of AAV5-EF1a-DIO-ChETA ${ }_{\text {TC }}$-EYFP or AAV5-EF1a-DIOEYFP into the LPBN of Htr2c-2A-iCre mice. (f) Photostimulation of ChETA $\mathrm{TC}^{- \text {expressing }}$ neurons $(20 \mathrm{~Hz}, 10 \mathrm{~ms}$ pulses, $1 \mathrm{~s}$ duration) efficiently drives photocurrents and action potentials in voltage-clamp (upper) and current-clamp (lower) recordings, respectively. (g) Closed-loop optogenetic photostimulation of $\mathrm{LPBN}^{\mathrm{Htr} 2 \mathrm{c}}$ neurons during a one-bottle assay (300 $\mathrm{mM} \mathrm{NaCl}$ ) after sodium depletion. Cumulative licks of $300 \mathrm{mM} \mathrm{NaCl}$ in AAV5-EF1aDIO-EYFP-injected mice (left) and AAV5-EF1a-DIO-ChETA ${ }_{\text {TC-EYFP-injected mice }}$ (right). EYFP N = 4 mice, ChETA ${ }_{T C}$-EYFP N $=4$ mice. (h) Total licks measured in AAV5EF1a-DIO-EYFP-injected mice and AAV5-EF1a-DIO-ChETA ${ }_{\text {TC }}$-EYFP-injected mice at the end of the experiment. Two-Way Repeated Measures ANOVA: photostimulation $(\mathrm{F}(1,6)=$ 14.26, $\mathrm{P}=0.0092)$, virus $(\mathrm{F}(1,6)=1.986, \mathrm{P}=0.2085)$, interaction $(\mathrm{F}(1,6)=27.37, \mathrm{P}=$ 0.002). EYFP $\mathrm{N}=4$ mice, $\mathrm{ChETA}_{\mathrm{TC}}-\mathrm{EYFP} \mathrm{N}=4$ mice. All post hoc tests done using the Bonferroni correction. All data represented as mean \pm s.e.m. $* * \mathrm{P}<0.01, * * * * \mathrm{P}<0.0001$. 
a

AAV-DIO-hM4Di-mCherry

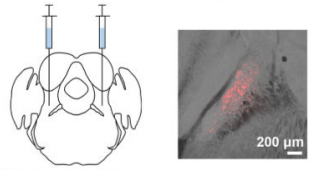

Htr2c-2A-iCre mice

d

Dehydration protcoco

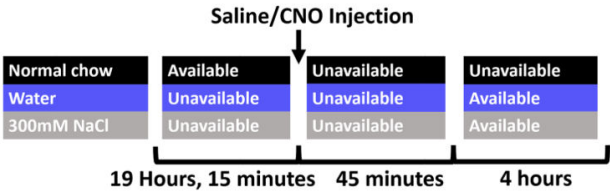

f

Euvolemia protocol

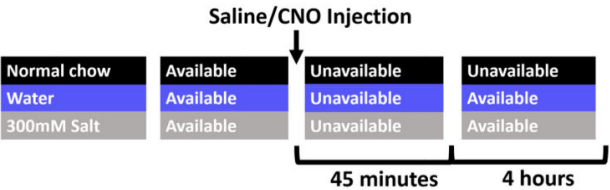

h

Euvolemia - KCI

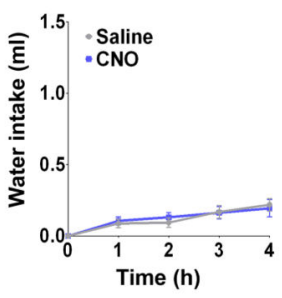

j

Fast-refeeding protocol

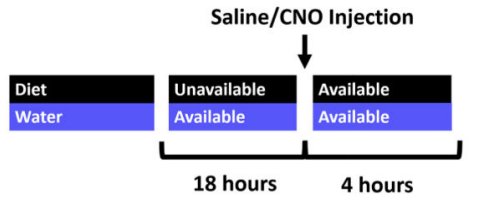

b

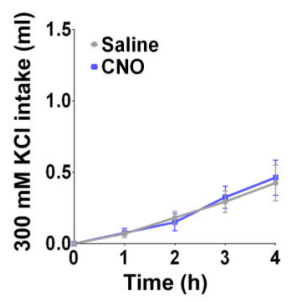

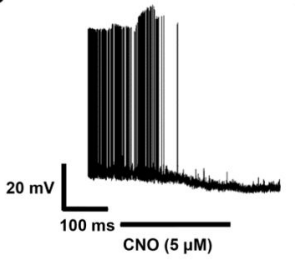

e

Dehydration - Two-bottle assay

g

i

k
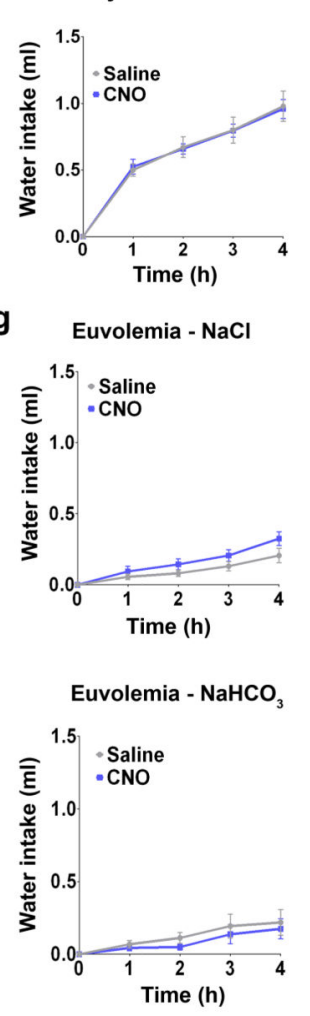

Fast-refeeding

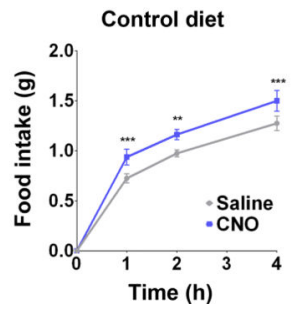

Codium depletion - Two-bottle assay
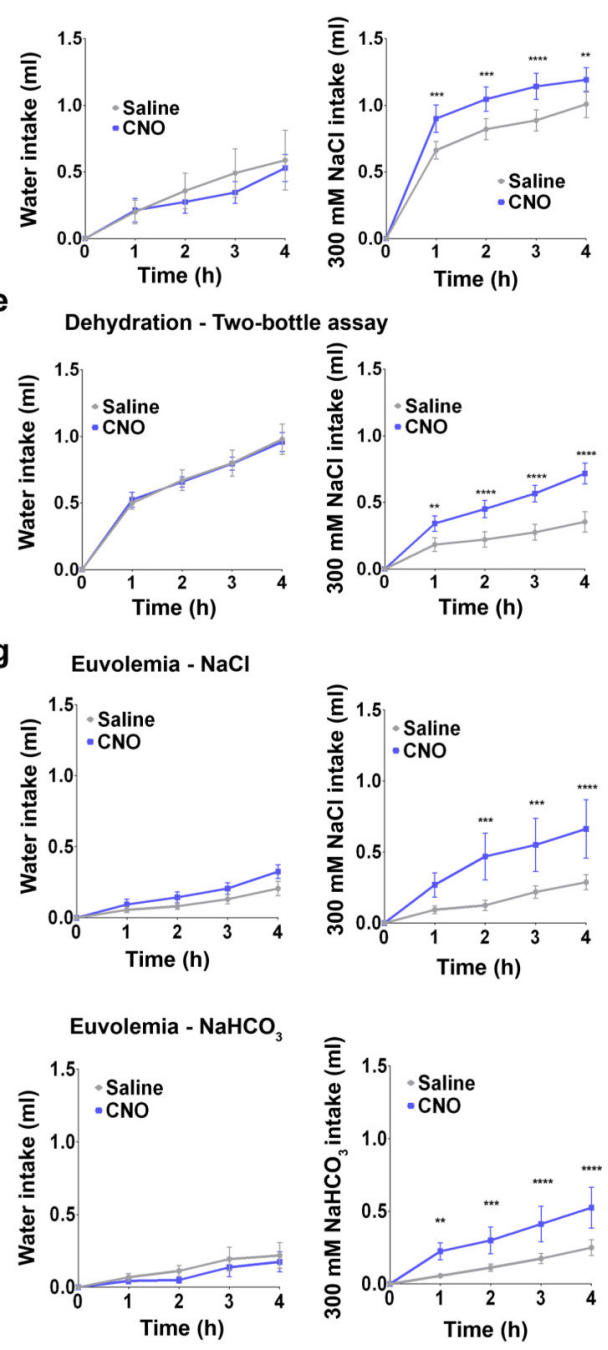

Sodium-deficient diet

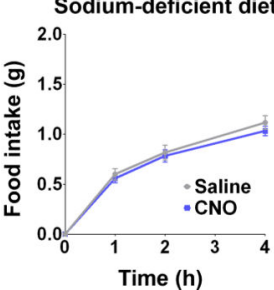

Figure 3. Inhibition of $\mathrm{LPBN}^{\mathrm{Htr} 2 \mathrm{c}}$ neurons increases sodium intake.

(a) Bilateral injection of AAV2-hSyn-DIO-hM4Di-mCherry into the LPBN of Htr2c-2AiCre mice (left). Representative image of injection site (right). Scale bar $=200 \mu \mathrm{m}$. (b) DREADDs validated through current clamp recordings. (c) Water intake during sodium depletion: Two-Way Repeated Measures ANOVA: time $(\mathrm{F}(4,40)=33.11, \mathrm{P}<0.0001)$, treatment $(\mathrm{F}(1,10)=0.8369, \mathrm{P}=0.3818)$, interaction $(\mathrm{F}(4,40)=1.712, \mathrm{P}=0.1663) .300$ $\mathrm{mM} \mathrm{NaCl}$ intake during sodium depletion: Two-Way Repeated Measures ANOVA: time $(F(4,40)=68.77, P<0.0001)$, treatment $(F(1,10)=10.57, P=0.0089)$, interaction $(F(4,40)$ 
$=7.546, \mathrm{P}=0.0001) . \mathrm{N}=11$. (d) Schematic illustration showing schedule for dehydration. (e) Water intake during dehydration: Two-Way Repeated Measures ANOVA: time $(\mathrm{F}(4,44)=$ 127.3, $\mathrm{P}<0.0001)$, treatment $(\mathrm{F}(1,11)=0.001088, \mathrm{P}=0.9743)$, interaction $(\mathrm{F}(4,44)=$ $0.09926, \mathrm{P}=0.9821) .300 \mathrm{mM} \mathrm{NaCl}$ intake during dehydration: Two-Way Repeated Measures ANOVA: time $(\mathrm{F}(4,44)=59.29, \mathrm{P}<0.0001)$, treatment $(\mathrm{F}(1,11)=9.495, \mathrm{P}=$ $0.0104)$, interaction $(F(4,44)=8.926, P<0.0001) . N=12$. (f) Schematic illustration showing schedule for euvolemia tests. (g) Water intake: Two-Way Repeated Measures ANOVA: time $(\mathrm{F}(4,28)=29.26, \mathrm{P}<0.0001)$, treatment $(\mathrm{F}(1,7)=4.019, \mathrm{P}=0.085)$, interaction $(\mathrm{F}(4,28)=1.334, \mathrm{P}=0.282) .300 \mathrm{mM} \mathrm{NaCl}$ intake: Two-Way Repeated Measures ANOVA: time $(\mathrm{F}(4,28)=12.04, \mathrm{P}<0.0001)$, treatment $(\mathrm{F}(1,7)=5.615, \mathrm{P}=$ $0.0496)$, interaction $(\mathrm{F}(4,28)=4.625 \mathrm{P},<0.0054) . \mathrm{N}=8$. (h) Water intake: Two-Way Repeated Measures ANOVA: time $(\mathrm{F}(4,28)=19.15, \mathrm{P}<0.0001)$, treatment $(\mathrm{F}(1,7)=$ $0.01671, \mathrm{P}=0.9008)$, interaction $(\mathrm{F}(4,28)=0.5804, \mathrm{P}=0.6793) .300 \mathrm{mM} \mathrm{KCl}$ intake: TwoWay Repeated Measures ANOVA: time $(\mathrm{F}(4,28)=13.26, \mathrm{P}<0.0001)$, treatment $(\mathrm{F}(1,7)=$ $0.02963, \mathrm{P}=0.8682)$, interaction $(\mathrm{F}(4,28)=0.4732, \mathrm{P}=0.7550) . \mathrm{N}=8$. (i) Water intake: Two-Way Repeated Measures ANOVA: time $(\mathrm{F}(4,28)=8.521, \mathrm{P}<0.0001)$, treatment $(\mathrm{F}(1$, $7)=0.5266, \mathrm{P}=0.4916)$, interaction $(\mathrm{F}(4,28)=0.2829, \mathrm{P}=0.8866) .300 \mathrm{mM} \mathrm{NaHCO}$ intake: Two-Way Repeated Measures ANOVA: time $(\mathrm{F}(4,28)=14.14, \mathrm{P}<0.0001)$, treatment $(\mathrm{F}(1,7)=8.089, \mathrm{P}=0.0249)$, interaction $(\mathrm{F}(4,28)=6.304, \mathrm{P}=0.0010) . \mathrm{N}=8 .(\mathbf{j})$ Schematic illustration showing schedule for fast-refeeding. (k) Control diet food intake $\mathrm{N}=$ 8 (left): Two-Way Repeated Measures ANOVA: time $(\mathrm{F}(3,21)=226.7, \mathrm{P}<0.0001)$, treatment $(\mathrm{F}(1,7)=13.06, \mathrm{P}=0.0086)$, interaction $(\mathrm{F}(3,21)=4.987, \mathrm{P}=0.0091)$. Sodiumdeficient diet food Intake $\mathrm{N}=12$ (right): Two-Way Repeated Measures ANOVA: time $(\mathrm{F}(3,33)=216.2, \mathrm{P}<0.0001)$, treatment $(\mathrm{F}(1,11)=0.7438, \mathrm{P}=0.4069)$, interaction $(\mathrm{F}(3$, $33)=0.4746, \mathrm{P}=0.7021$. All post hoc tests done using the Bonferroni correction. All data represented as mean \pm s.e.m. ${ }^{* *} \mathrm{P}<0.01, * * * \mathrm{P}<0.001, * * * * \mathrm{P}<0.0001$. 
a

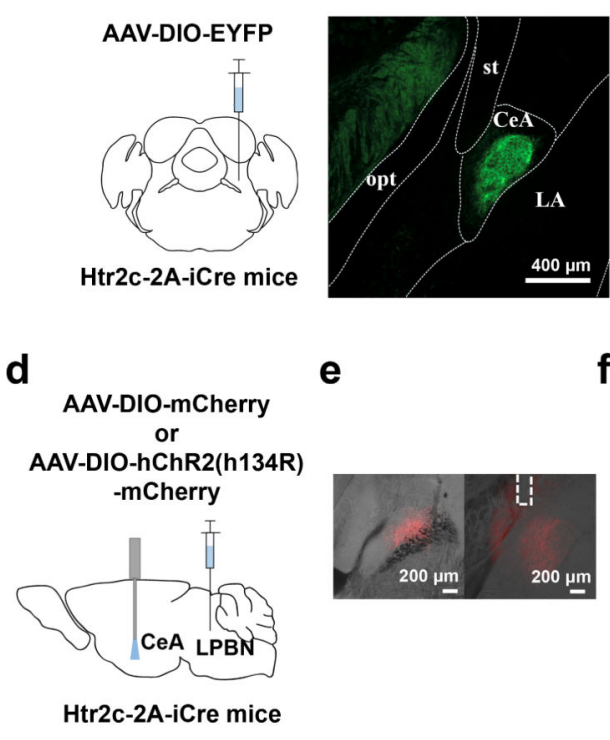

b

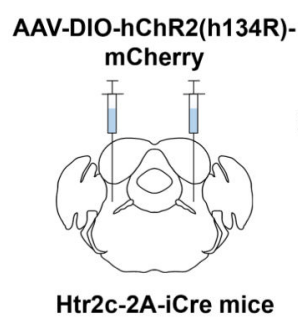

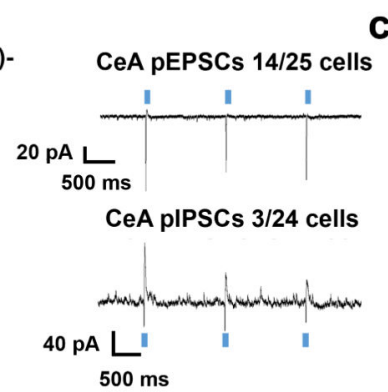

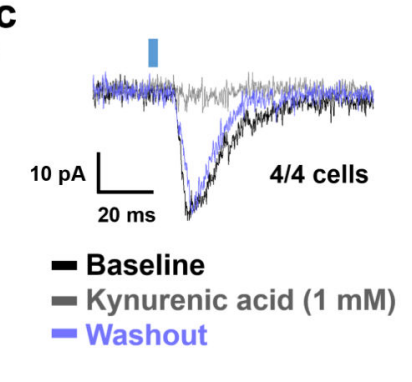

f

Sodium depletion - One-bottle assay

g
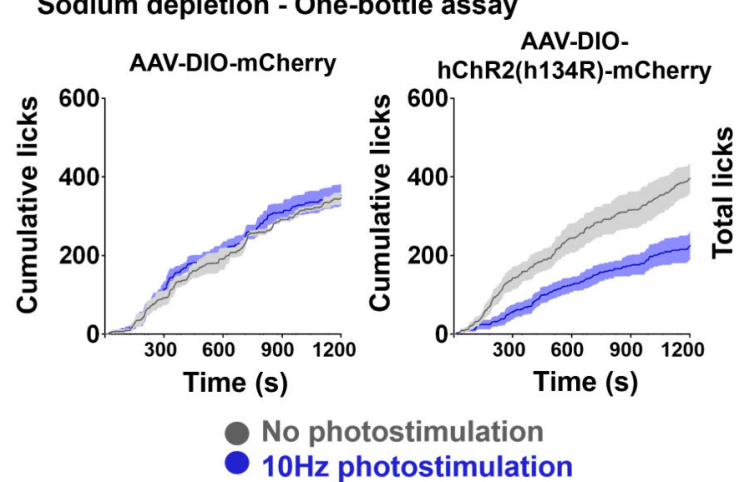

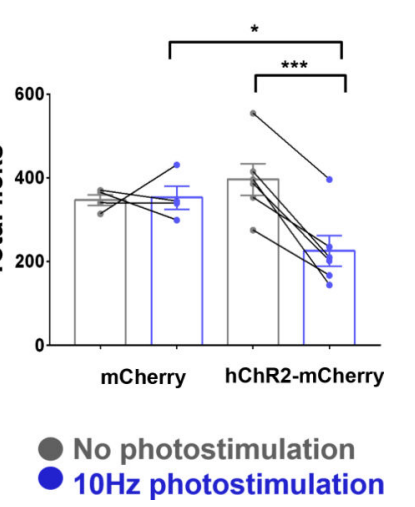

Figure 4. Stimulation of the $\mathrm{LPBN}^{\mathrm{Htr} 2 \mathrm{c}} \rightarrow \mathrm{CeA}$ projection suppresses sodium intake.

(a) Schematic of experiment. Unilateral injection of AAV5-EF1a-DIO-EYFP into the LPBN of Htr2c-2A-iCre mice to visualise axonal projections (left). CeA = central amygdala, $\mathrm{LA}=$ lateral amygdala, opt $=$ optic tract, $\mathrm{st}=$ stria terminalis. Scale bar $=400 \mathrm{um}$ (right). $\mathrm{N}=7$ mice. (b) Schematic of experiment. Bilateral injection of AAV2-EF1a-DIO-hChR2 (h134R)mCherry into the LPBN of Htr2c-2A-iCre mice (left). Voltage-clamp recordings taken at the $\mathrm{CeA}$ (right). Blue rectangles indicate times of photostimulation. (c) Kynurenic acid (1 mM) application abolishes pEPSCs at the CeA. Blue rectangle indicates time of photostimulation. (d) Schematic of experiment. Unilateral injection of AAV2-EF1a-DIO-hChR2 (h134R)mCherry into the LPBN of Htr2c-2A-iCre mice and implantation of an optic fibre ipsilaterally over the CeA. (e) Representative image of injection site (left), and representative image of fibre implantation site (right). Dashed lines indicate fibre placement. Scale bars $=200 \mu \mathrm{m}$. (f) Closed-loop optogenetic photostimulation of LPBN ${ }^{\mathrm{Htr} 2 \mathrm{c}}$ neurons during a one-bottle assay $(300 \mathrm{mM} \mathrm{NaCl})$ after sodium depletion. Cumulative licks of 300 $\mathrm{mM} \mathrm{NaCl}$ in AAV2-EF1a-DIO-mCherry-injected mice (left) and AAV2-EF1a-DIO-hChR2 (h134R)-mCherry-injected mice (right). mCherry $\mathrm{N}=4$ mice, hChR2-mCherry $\mathrm{N}=6$ mice. (g) Total licks measured in AAV2-EF1a-DIO-mCherry-injected mice and AAV2-EF1a-DIOhChR2 (h134R)-mCherry-injected mice at the end of the experiment. Two-Way Repeated Measures ANOVA: photostimulation $(\mathrm{F}(1,8)=15.61, \mathrm{P}=0.0042)$, virus $(\mathrm{F}(1,8)=0.7701, \mathrm{P}$ $=0.4058)$, interaction $(\mathrm{F}(1,8)=17.97, \mathrm{P}=0.00028)$. mCherry $\mathrm{N}=4$ mice, hChR2 $\mathrm{mCherry} \mathrm{N}=6$ mice. All post hoc tests done using the Bonferroni correction. All data represented as mean \pm s.e.m. $* \mathrm{P}<0.05, * * * \mathrm{P}<0.001$. 


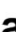

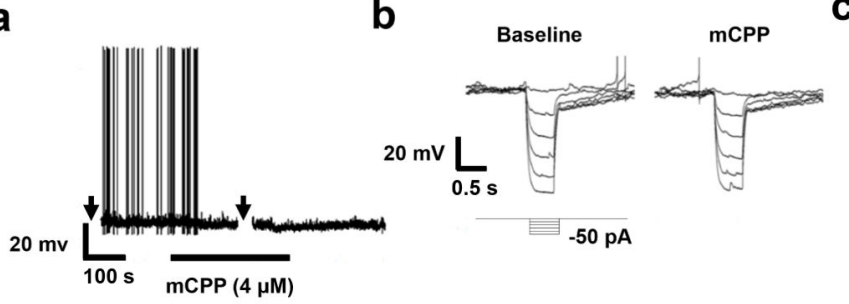

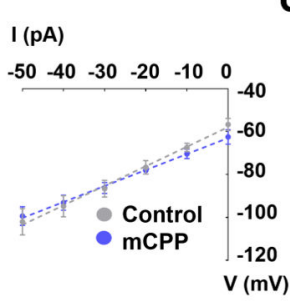

d

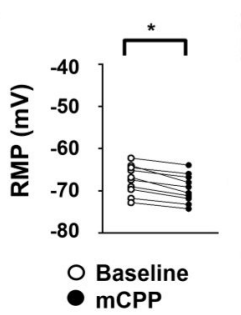

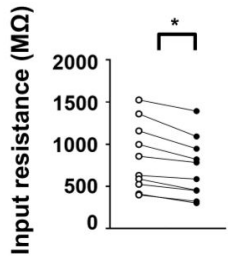

e

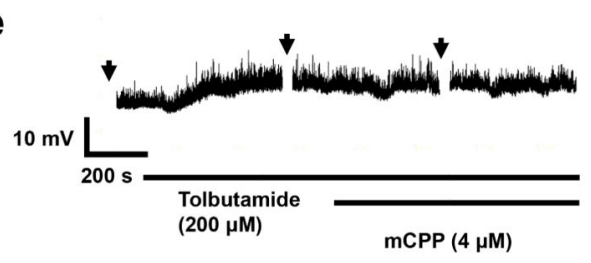

f

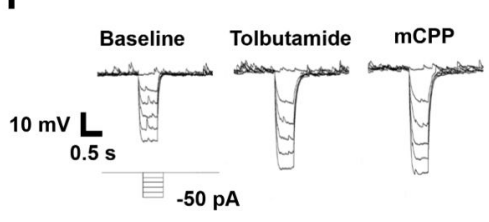

g

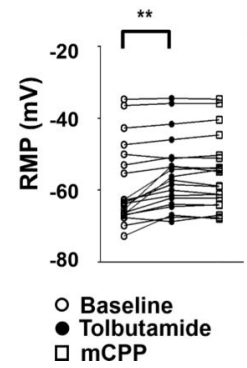

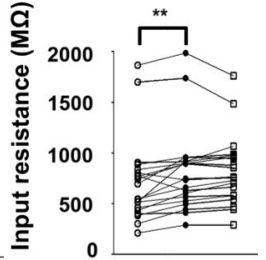

Figure 5. Htr2c inhibits LPBN neurons via $K_{A T P}$ channels.

(a) Representative current clamp recording of an $\mathrm{LPBN}^{\mathrm{Htr} 2 \mathrm{c}}$ neuron, showing hyperpolarisation in response to mCPP. Arrows indicate time at which current steps were applied. (b) Voltage deflections in response to hyperpolarising currents from the same neuron, showing decreased input resistance in response to mCPP. Current steps in trace made in $10 \mathrm{pA}$ increments from $-50 \mathrm{pA}$ to $0 \mathrm{pA}$. (c) Averaged I-V plot across responsive neurons, showing decreased input resistance in response to mCPP. Reversal potential was calculated to be $-86.9 \pm 4.6 \mathrm{mV}$. $\mathrm{n}=6$ cells. (d) Change in resting membrane potential (RMP) and input resistance across mCPP responsive neurons, Two-tailed Wilcoxon signed rank test, $\mathrm{P}=0.002 . \mathrm{n}=10$ cells. (e) Representative current-clamp recording of an $\mathrm{LPBN}^{\mathrm{Htr} 2 \mathrm{c}}$ neuron. Neurons depolarize in response to tolbutamide and no longer respond to mCPP. Arrows indicate time at which current steps were applied. (f) Voltage deflections in response to hyperpolarising currents from the same neuron, showing increased input resistance in response to tolbutamide but no change during $\mathrm{mCPP}$ application. Current steps in trace made in $10 \mathrm{pA}$ increments from $-50 \mathrm{pA}$ to $0 \mathrm{pA}$. (g) Individual data points for resting membrane potential (left) and input resistance (right) before and during tolbutamide application in all recorded cells. Mean depolarisation resulting from tolbutamide alone was $3.5 \pm 0.8 \mathrm{mV}$. RMP: Repeated measures ANOVA with a Greenhouse-Geisser correction $(\mathrm{F}(1.127,21.41)=19.059, \mathrm{P}=0.001)$. Post hoc tests using the Bonferroni correction. Input resistance: Repeated measures ANOVA with a Greenhouse-Geisser correction $(\mathrm{F}(1.376$, $26.51)=8.627, \mathrm{P}=0.0035$ ). All post hoc tests using the Bonferroni correction. $\mathrm{n}=20$ cells. All data represented as mean \pm s.e.m. $* \mathrm{P}<0.05 * * \mathrm{P}<0.01$. 
a

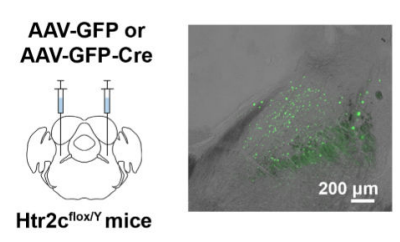

d

Sodium depletion - Two-bottle assay

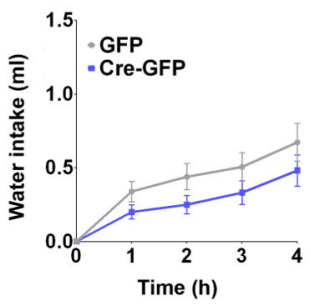

$\mathbf{f}$

Fast-refeeding

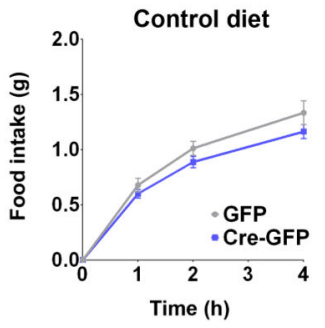

b

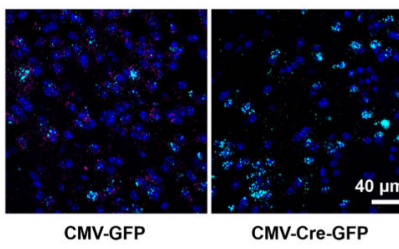

C

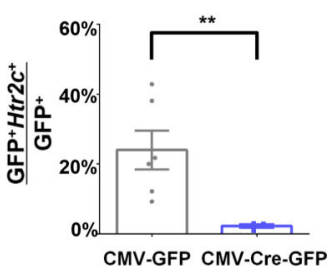

e

Dehydration - Two-bottle assay
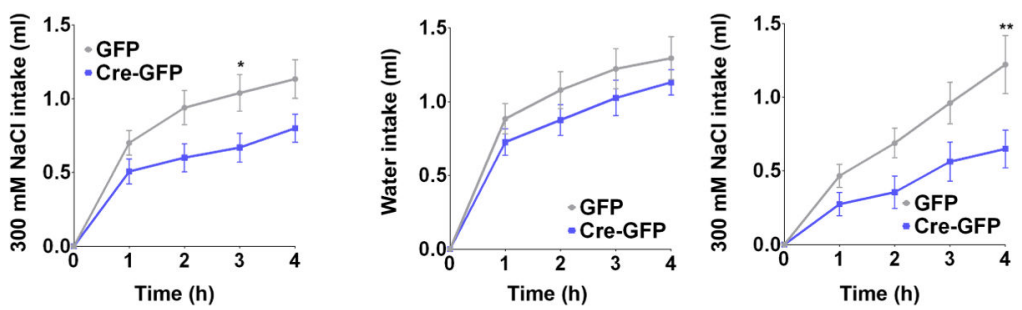

g

Euvolemia - Two-bottle assay
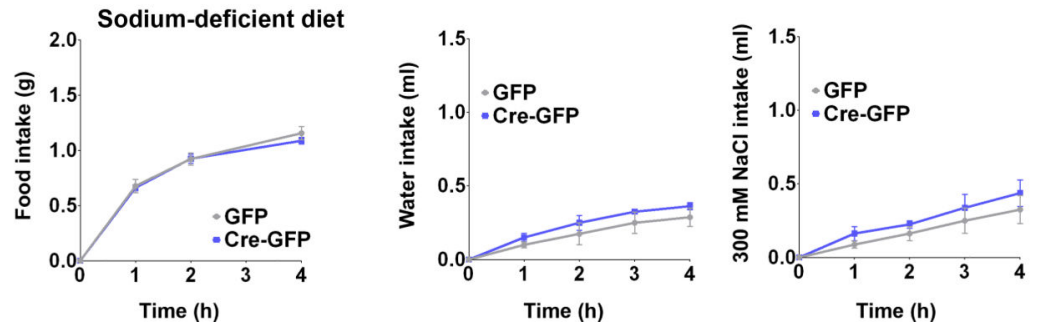

Figure 6. Htr2c in the LPBN is necessary to disinhibit sodium appetite during hypovolemia. (a) Schematic of experiment. Bilateral injections of either AAV5-CMV-GFP or AAV5CMV-Cre-GFP into Htr2 $\mathrm{c}^{\text {flox/Y }}$ mice (left). Representative image of injection site (right). Scale bar $=200 \mu \mathrm{m}$. (b) Representative images validating knockout of Htr2c through in situ hybridisation. Scale bar $=40 \mu \mathrm{m}$. (c) Quantification of Htr2c knockout. Two-tailed MannWhitney test, $\mathrm{P}=0.0095$. CMV-GFP N $=6$ mice. CMV-Cre-GFP N $=4$ mice. (d) Water intake during sodium depletion: Two-Way Repeated Measures ANOVA: time $(\mathrm{F}(4,60)=$ $39.08, \mathrm{P}<0.0001)$, treatment $(\mathrm{F}(1,15)=2.092, \mathrm{P}=0.1686)$, interaction $(\mathrm{F}(4,60)=1.389, \mathrm{P}$ $=0.2485) .300 \mathrm{mM} \mathrm{NaCl}$ intake during sodium depletion: Two-Way Repeated Measures ANOVA: time $(\mathrm{F}(4,60)=101.3, \mathrm{P}<0.0001)$, treatment $(\mathrm{F}(1,15)=4.521, \mathrm{P}=0.0505)$, interaction $(\mathrm{F}(4,60)=4.141, \mathrm{P}=0.005)$. CMV-GFP N $=9$ mice, CMV-Cre-GFP N $=8$ mice. (e) Water intake during dehydration: Two-Way Repeated Measures ANOVA: time $(\mathrm{F}(4,60)=140.1, \mathrm{P}<0.0001)$, treatment $(\mathrm{F}(1,15)=1.249, \mathrm{P}=0.2813)$, interaction $(\mathrm{F}(4,60)$ $=1.024, \mathrm{P}=0.4021) .300 \mathrm{mM} \mathrm{NaCl}$ intake during dehydration: Two-Way Repeated Measures ANOVA: time $(\mathrm{F}(4,60)=48.04, \mathrm{P}<0.0001)$, treatment $(\mathrm{F}(1,15)=5.117, \mathrm{P}=$ 0.039), interaction $(\mathrm{F}(4,60)=4.276, \mathrm{P}=0.0041)$. CMV-GFP N $=9$ mice, CMV-Cre-GFP N $=8$ mice. (f) Control diet food intake (left): Two-Way Repeated Measures ANOVA: time $(\mathrm{F}(3,45)=302.9, \mathrm{P}<0.0001)$, treatment $(\mathrm{F}(1,15)=1.976, \mathrm{P}=0.1802)$, interaction $(\mathrm{F}(3$, $45)=1.405, \mathrm{P}=0.2538$ ). Sodium-deficient diet food intake (right): Two-Way Repeated Measures ANOVA: time $(\mathrm{F}(3,45)=465.2, \mathrm{P}<0.0001)$, treatment $(\mathrm{F}(1,15)=0.1966, \mathrm{P}=$ 0.6638), interaction $(F(3,45)=0.5274, P=0.6657)$. CMV-GFP N $=9$ mice, CMV-Cre-GFP $\mathrm{N}=8$ mice. (g) Water intake during euvolemia: Two-Way Repeated Measures ANOVA: time 
$(\mathrm{F}(4,24)=36.98, \mathrm{P}<0.0001)$, treatment $(\mathrm{F}(1,6)=1.254, \mathrm{P}=0.3056)$, interaction $(\mathrm{F}(4,24)$ $=0.573, \mathrm{P}=0.6848) .300 \mathrm{mM} \mathrm{NaCl}$ intake during euvolemia: Two-Way Repeated Measures ANOVA: time $(\mathrm{F}(4,24)=25.79, \mathrm{P}<0.0001)$, treatment $(\mathrm{F}(1,6)=0.9208, \mathrm{P}=0.3743)$, interaction $(\mathrm{F}(4,24)=0.5215, \mathrm{P}=0.7208)$. CMV-GFP N $=4$ mice, CMV-Cre-GFP N $=4$ mice. All post hoc tests done using the Bonferroni correction. All data represented as mean \pm s.e.m. $* \mathrm{P}<0.05, * * \mathrm{P}<0.01$. 